\title{
Kaptajn Nørgaards Dagbog fra 1864.
}

Ved Knud olrik.

Johannes Christian Ørsted Nørgaard var født 1837 i Kobenhavn som søn af inspektør ved Rosenborg brøndanstalt E. A. Nørgaard og blev 1855 assistent ved brondanstalten, hvor han 1882 blev driftsinspektør. 1862 blev han sekondløjtnant i artilleriet; i 1864 var han kommandør i et afsnit af Dannevirkestillingen, senere af en skanse på Dybbøl, men var den meste tid knyttet til forsvaret af skanse $V$ nord for Fredericia.

I felten førte han indtil 15. maj en dagbog, som ejedes af hans svigersøn, nu afdøde godsejer L. Nellemann, Skovnæs ved Irrederikssund, tidligere Allingskovgaard. Bladene er til og med 7. maj revet ud af bogen, fordi Nørgaard efterhånden har sendt optegnelserne hjem. De bærer præg af at være skrevet under lidet gunstige forhold, på et tornyster, $i$ en barak o. s. v., hvilket vel bl. a. forklarer den ikke helt konsekvente tegnsætning. Denne er dog bibeholdt her, når lige undtages, at der hist og her er sat et punktum, hvor det øjensynligt mangler, f. ex. i slutningen af en linje eller ved enden af en dags meddelelser.

De første 3 uger er dagbogen her meddelt i sin helhed, derefter $\mathrm{i}$ forkortet form. Det lader sig jo ikke nægte, at de mange gentagelser angående dagliglivet i Fredericia og sidst på Fyn har mindre interesse. På den anden side er det fuldt forståeligt, at det materielle og tidkorten kommer til at fylde uforholdsmæssig meget $i$ en lang uvirksomheds tid. Dagbogens væsentlige kildeværdi ligger selvsagt $i$, at den giver et billede af, hvordan en ung, dannet officer tænker om forholdene, som de møder ham, eller som han hører om dem. Hertil skal dog bemærkes, at den kritik, der kommer frem, af hensyn til faren ved at fæstne sådan til papiret, er meget mådeholden. Ifølge meddelelse fra godsejer Nellemann rettede Nørgaard, som det også fremgår af hans korrespondancebog, alvorlige anker 
mod mangelen på forsyninger og anden dårlig forberedelse til krigen.

(Retskrivningen er naturligvis helt og holdent Norgaards egen. Af hensyn til nutidslæsere er (log mark, skilling og fod skrevet med bogstaver, mens tegnet for pund (

\section{4.}

\section{Februar.}

1. - Idag telegrapherede jeg voldsomt med Frederiksstad om Holstenernes Skjæbne der naturligvis forblev uafgjort. ${ }^{1}$ ) Jeg udsondrede dem derfor og lod dem blive hjemme, medens hele det avrige Mandskab maatte tage Stilling i Skandserne.")

2. - Det var kun i de to yderste Skandser at Mandskabet blev staaende, $i$ de andre fandtes ingen Hytter eller Noget som helst hvor de kunde være, saa at de gik tilbage, men de maa rimeligvis herud igjen imorgen.

3. - Kl 2 Morgen stillede Mandskabet til Udrykning da Fjender var i Nærheden. Kl 4 stod hver Mand paa sin Post. Natten var bælgmørk, det var derfor meget vanskeligt at ride uden at komme i Grøfterne. Jeg pidiskede ornkring fra clen ene Skandse til den anden, udenfor $\mathrm{Nr} 20$ peb 3 Kugler mig om Ørerne, hvilket forresten mærkværdigt nok slet ikke afficerede mig. Tylskerne skjøde tillige paa 2 Skildvagter der gik tilbage over Damningen, ${ }^{3}$ ) men skjøndt de fyrede paa 150 à 200 Alens Afstand og fyrede c 50 Skud fik de dog kun lavet et $\mathrm{Hul} i$ den Enes Støvleskaft. Ankommen til $\mathrm{Nr} 19$ lod jeg skyde 3 Skud efter en Colonne paa 20 Mand, der generede vore Skildvagter, den splittedes strax. Den ene Skildvagt mistede sin Tornyster. Ankommen til 21 paa Tilbagevejen fandt jeg her at Preusserne havde saaret en Mand i Inderlivet, men der var ellers ikke hændt Noget ligesaalidt som ved de andre Skandser. Kl 12 kom jeg hjem men Kl 6 blæstes der atter til Ulrykning og jeg red omkring hele Natten uden at der passerede Noget.

4. - Lige til K1 5 om Eftermiddagen red jeg omkring og kom saa endelig hjem, hvor jeg kvægede mig vert en blid Slummer til Kl 6 næste Morgen.

5. - Red ud Kl 6 og inspicerede alle skandserne, fra $\mathrm{Nr} 20$ blev cier skudt et Par Skud efter en Snees Mand, der vare gaaet ud paa

1) Det drejer sig om, hvorvidt holstenske soldater efter forbundsexekutionen i denne landsclel skulde hjemsendes eller ej.

$\left.{ }^{2}\right)$ Øst for Hollingsted midtvejs mellem Slesvig og Frederiksstad.

3) Over Reideå-oversvømmelsen var der bygget 7 dæmninger, der forsvaredes fra skanserne. 
Dæmningen og prøvet Isens Styrke med en Bjælke, de trak dem sirax tilbage. Ved min Hjemkomst Kl 3 fik jeg Meddelelse af Majoren om at Stillingen skulde forlades om Aftenen. Jeg var maalløs af Forbauselse. $\mathrm{Kl} 3 \frac{1}{2}$ fik jeg Telegram fra Wahl, ${ }^{4}$ ) med Ordre til at trække alle Kanonerne ud af Værkerne saasnart det blev mørkt, dirigere dem til Banen ved Ellingsted.5) Jeg matte derfor atter pidske af, det bedste jeg kunde, da jeg var noilt til selv at overbringe denne Ordre. De 11 Kanoner fik jeg paa Jernbanen, for 2 sprængte Hestene Forstillingerne, en tredie blev der ikke Tid til at føre med, de bleve fornaglede og smidt $\mathrm{i}$ Vandet. Jeg tog efter min Hjemkomst Afsked med Skolelæreren og hans Familie, de vare dybt rørte og Kl 10 red jeg med mine Folk og Infanteriet Nord paa. Veiret var nedera1'ægtigt, det sneede, hlæste, saa at Turen var Alt andet end behagelig. Vejen gik over Treja til Øster- og Vester Orsted, derfra til Husumerchausseen, her nordpaa.") Ved Daggry kom vi til et Sted med endeel Vand ved som jeg ikke veed. hvad var.

6. - Marschen fortsattes hele Natten. Hele Vejen saa man Folk vlive liggende $\mathrm{i}$ Grøfterne, det var en umaallelig Masse, der tabtes paa denne Maade. Hele Formidlagen gik Turen fremad. Henved Kl. 2 kom vi til Skovkro, de forudgaaende Afdelinger marcherede tildeels ind $\mathbf{i}$ Skoven ${ }^{7}$, deels toge de Plads udenfor. Jeg hørte Rygter om at vi skulde bivouakere om Natten i Skoven. Efter henved et Døgns Marsch var denne Udsigt jo ikke meget tillokkende, men det kunde dog interessere mig at see en saalan Bivouak, men det skuIde hlive meget værre. Jeg marcherede med mine Folk over mod den Plads, de andre Afdelinger indtoge, men paa Veien molte jeg Major Caroc, der unclerrettede mig om, at der var Kamp og at jeg maatte trække mig med mine Folk til Bov over Harreslev, muligen naa Crusaa. Naa vi drev saa af og naaede Harreslev, horte hele Veien Skydningen, det gik meget rask med Kanonskud, Preusserne skal have overdænget vore med Granater. Jeg havde stor Lyst til at hlive og see paa det, men jeg skulde jo sırge for' mine Folk, matte ikke udsætte dem for at blive tagne og maatte derfor gaa villere. I Harreslev søgte jeg forgjæves at faa noget'Mad, da jeg ikke kunde faa Noget, gik jeg ind i et Hus og lod Jens ${ }^{8}$ ) pakke min Madkurv ud, neppe var jeg færdig, før der blæstes til L'drykning alt Militair i Byen rykkede ud og jeg med, jeg rykkede mod Nord, paa Veien kom et Bud fra Majoren, at

\footnotetext{
officer.

s) $6 \mathrm{~km}$ n. n. ø. f. Hollingsted på den daværende bane RensborgHusum.

-) De 3 nævnte byer ligger ved Slesvig-Husum landlevej. Husumerchausseen er Flensborg-Husum landevej.

7) Hanved skov $5 \mathrm{~km}$ s. v. f. Flensborg.

B) N.s oppasser.
}

4) Febr. 1864 var Johan Vahl den højestkommanderende artilleri- 
vi maatte skynde os, da Fjenden var i Hælene paa os. Jeg fik mine Folk anbragte paa forskjellige Vogne og kom paa den Maade lidt hurtigere frem, men det varede ikke længe, før Veien var saa fuld af Vogne at den var aldeles spærret og vi kunde hverken komme frem eller tilbage. Vi kom nu ind i en Masse Vogne, der nok skulde hente Fourage i Bov, og dem maatte vi følge, saa det gik Fandens langsomt, thi hvert Øieblik maatte man holde stille $1 / 2$ Times Tid saa at Klokken blev 9 før vi kom til Bov. Her bleve 11 af Folkene paa Vognene og kjørte viclere uden at vide at jeg ikke var med og bleve saaledes borte. Efter moden Overveielse besluttede jeg at blive i Bov om Natten, da Folkene vare umaadelig udmattede og jeg selv ligeledes, jeg bestilte derfor Qvarteer, fik Noget tillivs af min Madkurv, krøb i Seng i et bitte Hul, hvor der laae 2 andre Officerer. Men jeg havde enclnu ikke trukket Tæppet op over mig før en af mine Underofficerer kom og meldte at nu trak alt Militair ud af Byen, hvorfor han mente at det var hedst vi trak med, jeg kunde jo ikke Andet end indrømme Rigtigheden heraf og var derfor strax ude af Sengen igjen og tilhest. Heldigvis for mine udmattede Folk afgik 2 Divisions Train paa samme Tid, jeg fik dem alle anbragte paa Vogne, nu gik det fremad men meget smaat, da Veien hvert Øieblik var spærret af Vogne, Kanoner etc. Veien var desurien frygtelig glat, ikke en Hest var skjærpet, og da Veien var meget bakket maatte derfor Folkene af Vognene hvert Øjeblik for enten at trække Vognene op ad Bakkerne eller holde tilbage, naar de skulde ned.

7. - Jeg har en Forestilling om at jeg den Nat talte med en Masse Bekjendte og Andre, men det er gjerne muligt at det er Løgn. Jeg red paa min Hest, anstrængte mig af yderste Evne for at see hvorledes Terrainet var, men det var umuligt; hvor jeg vendte Øiet hen stødte det paa Vægge, jeg red saaledes hele Natten i store Sale, pragtfuldt udstyrede med Søiler etc. Sneen havde en varm okkergul Farve, som jeg forgjæves speculerede paa, hvorledes den kunde faae. Over mig kunde jeg see Stjernerne som jeg ogsaa undertiden kunde skimte gjennem de mig omgivende Vægge, men ud af dette forhexede Rum kunde jeg ikke komme, undertiden red jeg ind i mørke Huler, langs dybe Afgrunde, og min Hest vilde stadig ned i Afgrunden, saa jeg maatte slaaes med Hesten for ikke at knække Halsen.") Og de Fandens Kanoner holdt der midt paa Veien, og der var ikke mere Plads paa Siderne end at en Stenged kunde have gaaet paa, men jeg vilde forbi og kom ogsaa lykkelig udenom alle Kanonerne. Jeg blev nu imidlertid mere og mere træt og jeg ønskede blot at jeg kunde lægge mig til at sove $\mathrm{i}$ en Vogn og lade Hesten følge bagefter. Dette

') Det var ikke ualmindeligt, at soldaterne og befalingsmændene så syner på tilbagetoget fra Dannevirke, navnlig dets sidste del hen imod Sønderborg. 
optog mig nu aldeles, jeg faldt i Søvn paa Hesten, men hvert Øieblik vaagnede jeg op og brølede: Rolf Harmsen lad mig saa komme op at kjøre, men saa var der aldrig Nogen, dette blev jeg ved med en Stund, det blev imidlertid lyst, men det generede inig ikke, jeg sov glat væk paa Hesten, rer heldigvis gik lige ud ad Landevejen, i Adsbøl stod jeg af, fik lidt Caffe og Smørrebrød, her traf jeg Schytte der laae her med 6te Batteri. Da Hesten var fodret red jeg videre, men det varede ikke læenge før jeg faldt i Søvn igjen. Jeg vaagnede ved at en Mand brolede til mig og spurgte mig om jeg ikke skulde til Sønderborg. Jeg gloede meget forbauset omkring og befandt mig midt paa en Mark et godt Stykke fra Landeveien. Naa jeg kom jo url paa Veien igjen og for ikke at falde i Søvn igjen og da Veien blev stærkt bakket og meget glat stod jeg af og trak Hesten det meste af Veien til Sønderborg. Ankommen hertil søgte jeg forst til Raadstuen for at faa Qvarteer anvist og fik dette hos Kjøbmand Holländer. Dernæst besørgedle jeg mine Folk indqvartorede. Jeg fik et udmærket gort Logis lıos nogle niageløs flinke Folk, og gik naturligvis tidlig i Seng for at udhvile mig efter de haarde Anstrengelser.

8. - Jeg meldte mig hos Oberst Vahl og fik Ordre til at rykke paa Vagt imorgen. Her er et frygteligt Røre i Byen. Vogne, Kanoner, Heste og Soldater opfylder Gaderne og det er ofte en complet I'mulighed at komme igjennem. Forresten er det meget interessant at see det mageløse Liv der hersker her, Noget man ikke er vant til at see $i$ en saa lille By. Soldater af alle mulige Vaabenarter vrimle paa Gaderne; der er gamle og unge Folk slesvigske Gendarmer til at holde Orden paa de Masser af Kjøretøier der findes, Ordonnantser, med flade blaae Huer, forresten som Dragoner, de have ingen Kapper, men istedetfor disse have de et hvidt ullent Dækken om dem bunden om Halsen med et Toug, det er en meget mærkværdig Paaklædning. Soldater i reglementeret Paaklædning rre blandede med de gamle Forstærkningsfolk i deres islandske Nattrøier og lyseblaa Feltkapper og Lærredstornystre. ${ }^{10}$ ) Af Artilleristerne have Nogle Kapper, Nogle Tapper, Andre ingen af Delene, Nogle gaar med Infanterikapper med hvide Knapper, da de gule ere slupne op, Nogle have Tornystre, Andre trække af med deres Tøi i store Poser eller i deres Buxer der ere bundne sammen forneden og tjene som Tværsæk, en fangen asterrigsk Husar drev ogsaa forbi, frygtelig lurvet, Træskostøvler, en lille Kappe af slavegraat Klæde, blaa Frakke og Papchacot (hvid). Livet her paa ciaclen er meget interessant Masser af Bekjendte traffer man her, jeg traf saaledes Lorentzen, han havde kun 35 Mand tilbage ved sit Compagni af 1ste Bataillon. Sorte Ras-

10) Da man manglede nunderingssager, gav man forstærkningsmændene en færøisk trøje i st. f. våbenfrakken. 
mussen traf jeg, han laae hos mig om Natten, han skal i Morgen til Fredericia, Marcussen traf jeg, han havde meget travlt og desuden en Mængde' andre bekjendte Lieutenanter.

9. - K1 8 rykkede jeg med mit Mandskab ud i Dybholstillingen, jeg blev Commandeur i Skandse Nr. 6, Centralskandsen og den største i hele Stillingen. ${ }^{11}$ ) Den er armeret med 16 Kanoner, hvoraf 5 84 tige, det er en nydelig Skandse, og i det Hele taget er Stillingen overordentlig smuk, dette er log Noget, som man maa kunne forsvare, det er sammentrængt, det er noget Anclet end den uendelige Dannevirkestilling. Her er 10 Skandser med 88 Kanoner. Om Sommeren maa her være mageløs deiligt, man kan se det nu men nu maa man argre sig over al den Snee, man skal vade $i$, da der ikke er noget Spor af en Forbindelsesvei mellem Skandserne. Det er en meget stor Feil ved Stillingen at der ikke er dækkede Veie mellem Skandserne, da derved Forbindelsen mellem dem umuliggjøres, thi Terrainet mellem Skandserne ligger aldeles blot for Fjendens Skud. Her findes ellers Kanoner af alle Slags ligefra 84 \& swre Granatkanoner og 36 4t Kuglekanoner til 6 Pund Kuglekanoner. Dagen i Skandsen gik terrmelig kjedeligt da der ikke var Noget at gjøre. Een Adspredelse havde jeg, idet der kom en civil Mand ind i Skandsen og saa sig on, hvorfor jeg maatte sende ham til Sonderborg ledsaget af 1 Undercorp. og 1 Constabel; han opgav at være Fuldmagtig hos Politimesteren $i$ Sonderborg, hvilket viste sig at vare rigtigi, men man maa være meget forsigtig med civile Folk her, thi forleden vare 2 saadanne komne ind i Skandsen med Arbeidsfolkene og skulde lige til at fornagle Kanoner, da de bleve opdagede. Om Aftenen kom Capitain $\mathrm{Sick}^{12}$ ) og vi laae om Natten sammen i Krucltmagazinet og sov.

10. - Paa Tilhageveien fra Skandsern? moxlte jeg Wildau, med hvem jeg fik en Passiar. I Sonderborg traf jeg paa Gaden Corporal Gerlach, hvem jeg omfavnede.

11. - Idag matte jeg rykke ud af mit gode Quarteer og fik et andet ækelt Hus anvist, men fik det byttet. Men ret var ikke meget berlre. I mit gamle Qvarteer ville Folkene kun have 1 Rallr for de 4 Dage jeg havde været rler. Jegr kom nu til at hoe sammen med Friis $i$ et Værelse med en Sopha men uden Seng. Jeg maatte derfor ligge paa Gulvet.

12. - Idag flyttede jeg igjen derfra og maatte letale $t$ Mark 8 Skilling for $1 \mathrm{Dag}$, jeg fik mit gamle Logis igjen, da min Vaxt havie varet hos Borgmesteren og berlt om at faap mig igjen.

11) Skanse V og VI omsluttes af den nuvarende Kongeskanse.

12) T. B. Sick var kaptajn ved artilleriet og kompagnichef, blev taget til fange 18. apr. Også kendt som komponist. 
13. - Jeg indgav i Dag en meget vidtloftig Rapport over Tilstanden i Hollingsted siden Krigens I'dbrucl, on det mislykkede Forsøg paa at redde Kanonerne samt on Tillagetoget. Jeg boer nu igjen hos Kjøbmand Holländer, han og hans Søster ere overordentlige flinke imod mig og den gamle Fader ligeledes. Kun Skade at jeg ingen Middagsmarl kan faae hos dem. Tingen or at de kan ikke faae det gorlt nok til mig og saa vil de slet ikke.

14. - Kl 6 maatte jeg ud af Fjerene KI 7 stillede Mandskabet og jeg rykkede med mine ud i Skandse $\mathrm{Nr} 10$, der danner hoire Floi af Stillingen, nerlad mod Alssumr. I)en er kun armeret mol $424 \mathrm{H}$ K. K. og 412 \& $\mathrm{Gr}$. K. Af Taget der tidligere beskyttede Blokhuset var der dannet $\&$ Barakker, urlenfor Skandsen, hvoraf den ene til den commanderende Artilleriofficer, o: jeg. Det var kun en lille en, man kunde ikke staap opreist, samme Facon som et Korthus af 22 Kort. ingen Lukke for Enden, men det var log altid et Læ. Da Jens kom med Madkurven spiste jeg Frokost, i hvilken Forretning jeg blev overrasket af Capt. Schjoller, der ogsia skulde paa Vagt i Nr 10. Han deltog med Glacle i min Frokost fik sig et herligt Stykke Nationalflæsk som jeg forrige Vagt havile faaet Fingre 1 og nu havde faaet kogt hjemme. Da jeg var færdig hermed matte jeg optalle Alt hvad cler fandtes i Skandse'n, da den forrige Vagtcommandeur havde gjort det skidt, det var ikke Inol'sont og tog meget lang Tid. Til Middag tog jeg mig naturligvis igjen en Bid Nationalflask. Kl. 4 kon en Infanterilieutenant Rogind, ler ogsaa var paa Vagt, og bad inig laane ham Ly da han var saa trat og sovnig. Han krob da ind $i$ min Hule og sov der til KI $\&$ næste Morgen. Henad Aftenen kom en af Folkene til mig og spurgte om de ikke turde byde Lieutenanten en Boeuf. Jo, det maatto de meget gjerne, han hemrrkede rigtignok at det var Hestekjorl men enfin, varm Boeuf ng do Kartofler let var jo en længe ukjenılt Herlighed. Nu begrndte der et nyt Liv. De havde en hel Deel $\mathrm{Kj}$ (r) og der hlev banket Boeuf i Bunker, snart flammerle et stort Baal i en Groft over Ilden hang 2 mægtige Kjecller med Kartofler og kogte og da de vare kogte kom Touren til Boeufen, der snart pirrede alle Sovende i Nesen saa at man saae den Ene efter den Anden stikke Næsen ud af Hulerne og snøfte. Endogsáa fra den naste Skanclse Nr 9 kom Lieutenant Friis ned til mig for at see hvor den Lugi kom fr. Han hev jo inviteret paa Boeuf og snart sade vi i Halmen i mit Hul med 2 store Boeufer og en voldsom Hoben clampende Kartofler for os. Da man nu puttede en Bid i Munden smagte den herligt, men saa skulde det jo tygges, hvilket var en meget vanskelig (Iperation, og Friis og jeg morede os gjensidig over hinandens Anstrengelser. Det maa have seet meget romisk ud udenfra, disse 2 arbejdende Mennesker oplyste af en Blandlygte, omgivne af Halmknipper, i Baggrunden en sovende Skikkelse. Naa 
den Svir fik jo ogsaa Ende. Efter Affodringen gik jeg med Friis over i Nr. 9 hvor der er en deilig Vagthytte med Kakkelovn, og da jeg her var bleven godt optøet, gik jeg tilbage, krøb ind $i$ min Kahyt, stoppede Aabningen til med Halm og lagde mig til at sove, og var saa heldig.aldeles ikke at blive forstyrret, saa at jeg sov til næste Morgen Kl. 7\%.

15. - Allerede $\mathrm{Kl} 81 / 2$ blev jeg afløst. Der var desværre ingen Leilighed derude til at foretage en Renselsesfest, saa man maatte drive af ind til Sønderborg græsselig snavset. Dels gik man nemlig og æltede i Snavs derude til midt op paa Benene, og nu havde man ligget i uldne Tæpper, der afhaarede saa at man var aldeles laadden. Men enfin, endelig kom man da til Sønderborg til sit Logis og blev der renset. Lieutenant Friis var saa god at tale min Sag varmt i Kjøkkenet i Hotel Alssund saa at jeg der sammen med ham fik Vandgrød og Ragout eller saadan noget.

16. - Stillede igjen til Vagt Kl 7, men fik den Besked at jeg skulde til Fredericia, jeg skulde faae nærmere Ordre. Da jeg havde spist Frokost æltede jeg ud paa Ladegaarden, ${ }^{13}$ ) hvor adskillige af de Herrer Lieutenanter ere blevne indlogerede; jeg traf her Lieutenant Haagensen, Hohlenberg, Brønnum, Tiedie, der sad og skrev paa en Prædiken, Elster af Kjøbenhavns Borgervæbning samt Koefoed af Bornholms Malice, ${ }^{14}$ ) der alle ere ansatte ved Artilleriet. Da jeg havde snakket en Stund med disse Mennesker og faaet mig en Kop varmt $\emptyset 1$, drev jeg af igjen og efter at have telegrapheret til Kjøbenhavn forsøgte jeg at faae noget Middagsmad. I 6 Huse var jeg inde uden at kunne faae Noget, i det 7de endelig fik jeg efter at have ventet en Timestid.

17. - Kl $7^{3 / 4}$ Morgen stillede jeg mit Commando bestaaende af 1 Lieutenant 4 Underofficerer og 173 Mand ved Havnen. Men vi bleve ikke indskibede før Kl 11. Det var Damp.skibet Valdemar, der skulde føre os til Faaborg. Foruden mit Masdskab var der endeel Infanteri ombord saa at der i det Hele var c 500 Mand. Imod Sædvane i Dampskibe var Alt overcirdentlig billigt. Jeg gjorde ombord Bekjendtskab med en Købmand $\mathrm{C}$ Lund fra Faaborg, der tilbød mig sit Hus til Ophold, medens jeg var i Faaborg, hvilket jeg naturligvis med Glæde tog imod. Ankommen til Faaborg sørgede jeg straks for Qvarteer til Folkene og begav mig dernæst hen til Kjøbmand Lund. Det var allerede mørkt, saa at jeg havde ingen Lejlighed til at se Noget af Byen. Da jeg havde ordnet mit Toilette kom jeg ned

13) Sønderborg ladegård s. ø. f. byen.

14) Bornholms milits, hvori Bornholmerne aftjente deres værnepligt, var øens gamle væbning, der oprettedes 1613 som støttepunkt for den danske flåde. Den ophævedes 1867 . 
til Familien, hvor jeg strax kom tilbords og fik en udmærket Boeuf tilligemed en brillant Rødvin, samt mange Undskyldninger, fordi man ikke kunde byde mig mere end een Ret. Fruen var nydelig desuden fandtes der en Cousine til Fruen, der var ganske net. Nu gik det naturligvis løs paa Fortællinger om hvorledes man havde havt det og hvad man havde døiet, og Tiden svandt saaledes paa en meget behagelig Maade.

18. - Kl 9 satte jeg Folkene jgang ad Assens til, betalte Qvarteer for Folkene, hvilket beløb sig til 3 Rdlr 2 Sk. for 177 Mand, det er nemlig $13 / 5 \mathrm{Sk}$. for Menige og $3^{1 / 5} \mathrm{Sk}$. for Underofficerer. Jeg fik re-. quiereret 4 Vogne; ifølge Marchordren skulde jeg have 2 Vogne, hver forspændt med 4 Heste til Befordring af mig og min Adjudant, men for at kunne befordre Mandskabets Tornystre og Poser tog jeg istedetfor 4 Vogne hver med 2 Heste. Jeg fik dernæst en urlmærket Frokost og Kjøbmand Lund udbad sig Tilladelse til at see til min Madkurv, hvilket han gjorde saa godt at da jeg selv saae til den fandt jeg foruden andre gode Spisevarer 1 Daase Sardiner en Flaske udmærket gl. Rom og en Flaske do. Sherry. Da jeg havde taget Afsked med den vakkre Familie satte jeg mig paa min Vogn og naaede snart Colonnen og gik saa tilfods saalænge jeg kunde. Jeg har faaet en Hævelse under min venstre Fod saa at det generer mig at gaae. I Mørkningen kom vi til Assens, ner varede det en gruelig Tid før jeg kunde faae Qvartéer hos Apotheker Strøyberg. Det var en meget flink gammel Mand han lever allene med en gammel Cousine saa der er jo ikke meget Liv i Huset. Da Kl blev 9 bad han om Undskyldning og gik $\mathrm{i}$ Klubben og jeg sad lidt og underholdt mig med den aldrende Cousine, hvorpaa jeg gik i Seng.

19. - Kl 8 Morgen marcherede vi videre. Folkene vare temmelig trætte. I Stubberup ${ }^{15}$ ) requiererede jeg 2 Vogne til, endeel af Folkene leiede selv Vogne, andre fik Bønderne til at kjøre for dem og paa denne Maade fik jeg dem nasten alle paa Vogne. I Udby ${ }^{16}$ ) gjorde vi Holdt en Timestid, jeg besøgte her Præsten Heilmann en Fætter til Apothekeren, og var hos ham medens Folkene udhvilede. Da vi kom til Middelfart var det Skumring, her varede det ogsaa temmelig læenge før jeg fik Qvartererne ordnede. Jeg blev selv indqvarteret hos Kjøbmand P. Christensen. Her blev jeg strax efter fuldendt Toilette fodret med en saadan Bunke stuvede Muslinger at jeg troede at jeg havde en græsselig Mavepine, men det gik dog ikke. Manden var i Selskab om Aftenen, jeg sad og snakkede med Konen og hendes gamle Onkel til Klokken henad 11 da jeg forføiede mig til Seng i det mindste Sovekammer jeg nogensincle har seet. Det havde

15) $10 \mathrm{~km}$ fra Assens.

16) $13 \mathrm{~km}$ længere fremme. 
samme Længde som Sengen og den dobbelte Bredle som samme saa at der var ikke Plads til min Kuffert derinde.

20. - Kl 9 marcherede vi til Strib, hvor vi kom Kl 11. Vi forefandt her en Masse Folk, der ligeletes skulde over og mødte Afdelinger paa Veien der gik tilhage, da de forst kunde komme over om Aftenen. Hele Transporten skete nemlig med det lille Dampskib Fulton, der slæbte en Transportbaad. Ved at tale med den Marinelieutenant der ledede Indskibningen og forestille ham af hvilken Vigtighed det var at jeg hurtig kom over med mit Mandskab da man i Fredericia havde Kanoner men Ingen der kunde betjene dem, ved disse Forestillinger lykkedes det mig at faa Halvielen af Mandskabet over $\mathrm{Kl}:$, Halvdelen Kl 3. Ankommen til Fredericia samlede jeg mine Folk og marcherede til Commandanten ${ }^{17}$ ) og her fra til Artillericommandoen. Her bleve Folkene, og jeg blev anmodet om at henvende mig til Capt. Mønster og maatte nu pidske Byen om for at finde denne, og falclt da endelig over ham paa Gaden. Jeg kunde tilsilst næsten ikke staae paa Benene mere, Brolagningen her er ganske nederdrægtig, Gaderne regelmassige og ikke til at kjende fra hinanden, saa at man har meget vanskeligt ved at fincle Vei, navnlig i Morke. Om Aftenen er her balmorkt, vel findes her endeel af de gamle kjøbenhavnske Gadetranlygter, men de ere ikke tandte, da der vistnok findes Folk der ville paastaae at det er Maaneskin. Jeg hlev indqvarteret i Prindsessegade hos Skrædler Ebbesen. Sengen var temmelig simpel, navnlig det ene Lagen var nasten illusorisk, da der kun var meget lidt tillage af det. Folkene vare forresten meget flinke, men de havde kun 1 Lysestage. Jeg hlev strax tracteret merl stegt Flask og Katofler (som Skradilerkonen kaldte dem).

21. - Idag dinglede jeg onkring og lesane Byen, der var Alt andet end interessant. Jeg gik det Halve af Volden rundt om Formiddagen. det er noget Lignende som Kjobenhavns Vold, men Bastionerne ere forsynede med hoie Cavallerer ${ }^{14}$ ), med svare Kanoner, der beliersker Omegnen og hvorfa man har en udmarket l'dsigt over By, Land og Vand. Da jeg kom ned i Byen, molte jeg P. Svendsen, og ved Hotel Victoria, hvor man spiser, naar man kan faae Noget, motite Jenson og Jelstrup, inde i Gjastestuen fandt jeg Poulsen, Petri og Jargensen. Jeg snyltede mig incl ved Bordet og lod som on jeg val Alomment og fik paa den Marale en meget god Middagsmad Efter IBordet hesalas jog med Jolstrup Resten af Volden og cla jegr var kommen hjem fik jeg Parolen med orelre til at afgata til zllet Compagui, og mololte migg hos Captain simhidt iaften $\mathrm{Kl}$ \%. Inet var nu en stieg i Reguingen

17) General Lumbing.

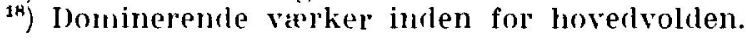


da jeg skulde spille L'hombre hos Jelstrup med Rasmussen og Fibiger Kl 7. Jeg kom op til Capitainen Kl 7 og fik her Ordre til at overtage Skandse $\mathrm{Nr} 5^{18}$ ) og der imorgen til 9 Kanoner lagge Budske, anbringe Kanonerne paa deres Pladser sumt fylde Magazinerne med Ladininger Granater etc. KI blev 9 inden vi hlev færdige med disse Ordrer. Jeg gik da hen til Jelstrup, hvor jeg traf Rasmussen og Fibiger ng fik noget Forter, da jeg var meget flau, men L’hombren gik naturligvis i Varisken.

2.2. - Da jeg storl op imorges kunde jeg nasten ikke staae paa den ene Fod, havde saa ondt $i$ Halsen at jeg ikke kunde synke, saa ondt i Kjaverne at jeg ikke kuncle tygge og saa ondt i Hoverlet, at jeg ikke kunde tænke, i hvilken Anledning jeg meldte mig syg. Om Formiddagen kom Jean Hansen ind til mig, hvilket jo glærlede mig meget. Han tog mig med hen til en Kjobmand Riemens'hneider hvor jeg fik Middagsmad, da der den Dag nanglede Een ved Bordet, ellers havde jeg ikke faret Noget. Vi aftalte en L'hombre hos mig til om Aftenen med Jelstrup og Lieutn. l)encker; men om Eftermidrlagen blev hele Byen omqvarteret saa vi forst hlev samlede $\mathrm{Kl} 91 / 2$ og sala var det jo for seent. Min Vært fik urlvirket hos Borgemester og laad at jeg kunde blive hos ham, da han norig vilde af merl mig, skjøndt jeg egentlig ligesaa gjerne var flyttet, thi Sengen er ikke god. Brevene hjemmefra tilligenıed Addresselırev paa en l'akke fik jeg igaar, men Pakken kan jeg sgu ikke faa Fingre $i$....

23. - Endnu syg. Brugte Tialen til at skrive Breve til Tutein, Wibroe og Kjøbmand C. Lund i Faahorg. Kl $21 / 2$ modtog jeg Telegraphrlepesche fra Peter"0) om Afsendelsen af Brevene som jeg hemarket hap faaet. Hvad Midlagsmad angaar, da spurgte Skraddermadamen mig nu on jeg vilde have en Tallerken Hyldeharsuppe og 1/2 Bolle, hvilket jeg naturligvis med Glade tog imorl. Forresten kan jeg saa gnave af mit Nationalflipsk. Naa jeg delicatererle mig altsaa med Hyldebarsuppen, der forresten saae alt Andet end appetittelig ud, men den glod jo med den halve Bolle og jeg kom dygtig til at svede af drn. Jolstrup og Jean Hansen havde nu lovet at kormme hen til nig og spille den L'hombre vi endnu ikke have faaet. $\mathrm{Kl} 71 / 2 \mathrm{kom}$ Jelstrup men Jean Hansen kom slet ikke, hvorudover Jelstrup og jeg bleve saa grasselig gale i vore Hoveder og bandede hannen frygteligt. Men det hjalp jo ikke, han hlev horte og vi fik heller ingen I.'hombre den Aften. Iet lader tik at vare meget vanskeligt at faa I.homlire her i Byen.

24 - Kl. \& Morgen meldte jeg mig rask. Ticlen paa hvilken man skulde stille om Morgenen var imidlertid bleven forandret til Kl. 7

19) Den sydligste af de 5 skanser nord for fustningen.

20) N.s hror, senere goneralagent i Wantsheck. 
saa den hele Historie var dreven af, da jeg kom. Naa det var jo ingen Ulykke $i$, jeg fik Lov til at gaa hjem igjen .... Derpaa gik jeg ud og besogte Jean Hansen, der var paa Vagt ved Kongens Port. Han bad mig komme om Aftenen og spille L'hombre og tage Folk med. Jeg drev saa hen og besaae det Quarteer der er anvist mig, men fandt mig ikke beføiet til at flytte, da Værelset kun indeholdt 1 Seng og 1 Stol, og forresten Intet. Kl 7 gik jeg op til Capitainen, her er nemlig den ulykkelige Skik at alle Lieutenanterne møde hver Aften hos Capitainen Kl 7 for at modtage Ordrer. Ordrer er der imidlertid sjelden, men dog bliver man opholdt hos Capitainen med Ingenting til $\mathrm{Kl} \mathrm{9,} \mathrm{og} \mathrm{saalerles} \mathrm{ogsaa} \mathrm{iaften} \mathrm{og} \mathrm{saa} \mathrm{inviterede} \mathrm{han} \mathrm{endda} \mathrm{hele}$ Banden hen til Conditoren paa Portviin og Kager. Den hoppede jeg naturligvis ikke paa men benede ucl til Jean hvor jeg imidlertid først kom Kl 91/2 og fik paa denne Maade heller ingen L'hombre den Aften. Nei, naar man saaledes skal orleìgge alle sine Aftener er det virkelig temmelig kjedeligt.

25. - Kl 7 Morgen stillede jeg for at gaae paa Exercits, da imidlertid alt mit Mandskab skulde paa Vagt Kl $2 \mathrm{gg}$ derfor være fri om Formiddagen var der ikke Noget for mig at gjøre, jeg kunde gjerne drysse hjem igjen. Hvad skulde jeg nu bestille? Efter at have læst Commandeursergeantens Aviser gik jeg paa Kroen og spiste Froknst, skjøndt Kl kun var 81/2, og saa, ja saa gık jeg hjem til Skrædderen og skrev hjem; dernæst kom Jelstrup og holdt mig med Selskab, saa gik jeg hen til Fru Riemenschneider og spurgle om jeg ikke tilfældigvis skulde kunne faa Lov til at spise til Middag hos hende, da jeg skulde paa Vagt og tilfulde indsaae det Umulige $i$ at faa Noget paa Kroen. Jo Gudbevares det kunde jeg saa udmærket, Lieuten. Hoffmann kom ikke idag, saa at det kunde jeg deiligt. Saa kom Manden og udtalte det Magtsprog, Lieuten. Nørgaard kan spise her hver Dag, saa maa min Kone rette sig derefter. Fruen svarede at det blev dog vel egentlig hende der raadede $\mathbf{i}$ det Capitel, men saa længe hun var i Byen skulde jeg ikke savne Middagsmad, i hvilken Anledning jeg efter Kl 2 at have ladet min Vagtparade afmarchere spiste hos Riemenschneiders. Jeg skulde nu paa Vagt, jeg skulde vaage over de 5 Skandser der danne den befæstede Leir Nord for Byen. Mandskabet var naaet derud $\mathrm{Kl} 2$ jeg kom selv derıd Kl 4 og gjennemgik nu hele Stillingen. Skandserne, der ere 5 i Antal og armerede med c. 80 Stk Skyts af forskellig Caliber, indeslutte, tilligemed Stranden, det Stykke Land, der ligger Nord for Fredericia op til Treldeskov. Veiret blev henad Aften ganske deiligt, det var blikstille og meget mildt, saa jeg benyttede Tiden til at see mig om. Terrainet er temmelig høit, henad Stranden til bliver det meget couperet navnlig paa enkelte Steder, paa andre Steder gaar Landet jevnt ud til Stranden hvor det falder meget brat af $i$ en Høide af 100 Fod. Havet var alde- 
les speilglat ikke en Vind rørte sig og fra Høiden var Udsigten udmærket over Beltet til Byens bratte Kyster, mod Nord langs Kysten op til Treldeskov. Mod Syd havde man Fredericia med dens Fæstningsværker og Bygninger, mod Vest hvor vi skulde vente Preusserne var der Intet at see, ikke saa meget som en Landsbykirke. Jeg spadserede om saalænge det var lyst, skjønt det var temmelig trættende da det formedelst Tøveiret var et grueligt Flte derude. Da jeg ikke kunde see mere begav jeg mig ind i mit Blokhus og besaae det Sted hvor jeg skulde hvile mine modige Been. Vagthytte findes nemlig ikke, man opholder sig i Blokhuset, der er alt Andet end tæt, her findes noget Halm samt nogle Tæpper til Vagtmandskabets Beqvemmelighed. Til Officeren der har Vagt er der bleven afdeelt et Hjørne ved Hjælp af 2 Brædder indenfor hvilke der findes Halm, Muus og et grønt Tæppe. Capitainen har endvidere paa eget An- og Tilsvar forsynet Vagtcommandeuren med et Bord og en Havestol saa at man jo har det efter Omstændigheden ganske fiint. Náa jeg fik nu fat i en Lygte, fik tændt Lys og satte mig til at studere Revue des deux mondes, indtil jeg blev sulten da jeg soldede i rogede Gaasebryster og et Stykke hollandsk Ost som jeg har kjøbt hos Peter Hassing, der desværre ikke har mere af den, jeg tror i det Hele taget ikke at man kan faae Ost mere i Byen. Kl $9 \frac{1}{2}$ lagde jeg mig paa mit Leie, der efter Omstændighederne var udmærket, da min Oppasser havde bragt mine 2 uldne Tæpper og min Slobrok med ud, og jeg sov derfor meget godt.

26. - Kl 2 Morgen gik jeg ud og visiterede Skandserne hvilket egentlig ikke var morsomt, da man for det Første maatte gaae og ælte og for det Andet havde man vanskeligt ved at finde dem, da der ingen Vei findes imellem dem, men det lykkedes jo tilsidst og Kl 4 kom jeg tilbage til min Skandse efter fuldendt Inspicering, og lagde mig til at sove til Kl 8 Morgen. Jeg havde nu ikke en Smule at bestille og Tiden gik derfor smaat, heldigvis kom Svendsen ud for at exercere med sine Folk i Skandsen og Jelstrup kom for at besoge mig, i hvilken Andledning de bleve tracterede med Kjøbmand Lunds Sardiner og Mutters Solbærrom, som de fandt udmærket. Endelig Kl $2^{3 / 4}$ slog Afløsningens Time og jeg benede hen til Fru Riemenschneider, hvor de saa er saa skarnagtige at tractere mig med Vælling og Torsk! Heldigvis havde jeg indtaget en solid Frokost, saa det gjorde ikke Noget, men det er dog krænkende....

Nu havde jeg lovet at komme op til Jean Hansen og spille L'hombre, men først skulde jeg jo til Capitainen. Jeg gik altsaa derhen, men Kl 7 præcis var han ikke kommen hjem, i hvilken Anledning jeg jo øjeblikkelig stak af, men naturligvis mødte jeg ham udenfor Porten, men slap dog for at gaae op igjen, da jeg spurgte ham om der var specielle Ordrer til mig, da jeg gjerne vilde gaae. 
Jeg gik nu øjeblikkelig op til Jean og fik den L'hombre som jeg nu længe har arbeidet paa at faae igang. Jeg spillede foruden med Jean med Lieuten. Albeck og Dencker begge af Infanteriet.

27. - Stillede Kl 7 Morgen. Infamt Snevejr. Desuagtet maatte vi jo ud til Exercits etc. Naa vi dinglede af. Vi vare 4 Officerer der fulgtes ad, og da Veiret stadig var bleven varre stode vi ved min Skandse og delibererede om vi ikke skulde lade Mandskabet gaae hjem igjen, men saa kommer Capitainen og glæder os med den Efterretning at vi skulde blive staaende $i$ Skandserne for at dække et muligt Tilbagetog af Oberst Neergaards Brigade. ${ }^{21}$ ) Vi stode nu her i et grueligt Sneveir et Par Timer, saa klarede det op, det vil sige klart blev det ikke, men det holdt dog op at snee og der kom nu en saa tæt Taage at man næsten ikke kunde see over Graven udenfor Skandsen. En Spion havde meddelt at Preusserne vilde foretage et Hovedangreb, vi have endnu ikke seet Spor af dem, og i den Anledning kom Alt paa Benene. Kun 13de Regiment med Jean Hansen samt 6 Kanoner bleve i Byen, og de stode opmarcherede paa Gaden fra Kl 9-3. Fjenden hverken hørte eller saae man noget til. Jeg var: jo specielt heldig stillet da jeg har faaet Skandse $\mathrm{Nr} 5$ den eneste, hvor der hverken findes Blokhus, Barakker eller noget andet Ly, og saa har jeg ovenikjøbet den Fordeel at naar Skydningen fra Volden begynder, har man der meget vanskeligt ved at lade være at sende mig den ene Granat i Nakken efter den anden. Her i denne Skandse eller Mark, hvad man vil kalde den, stod jeg nu og gloede med mit Mandskabet fra Kl 7-3, hvilket var alt Andet end morsomt. Naa det fik man jo ogsaa Ende paa. Kl 3 fik vi Lov til at gaae hjem da Spionens Beretning var Løgn. Se saaledes gaar det, saasnart En fortæller en eller anden Røverhistorie, strax hele Besætningen paa Benene og da de nu have begyndt at allarmere os, gaaer det vel paa hver Gang, Tydskerne kunne jo let gjøre det, de behøver blot at sende en Snees Mand et eller andet Sted hen, saa staaer hele Fredericia og venter paa hvad der nu skal skee. Det meest comiske ved Historien er dog egentlig at medens det Batteri, der blev her i Byen stod med sine 6 Kanoner opmarscherede i Gaderne og med Hestene forspændte fra $9-3$ havde de 2 Kanoner af Batteriet der var ude paa Forpost det meget godt, Hestene stode i deres Stalde hele Dagen og Mandskabet plejede sig paa det Bedste. Det er noget aparte at allarmere Forposterne fra Fæstningen, i Reglen er det jo Fæstningen der allarmeres fra Forposterne... [L'hombre om aftenen].

28. - Stillede som sædvanlig Kl 7 og marcherede ud til Skandsen hvor vi havde Kanonexercits til Kl 11. Græsselig søvnig. Sov hjemme

$\left.{ }^{21}\right)$ Neergaards brigade havde siden 19. febr. haft stilling bag Randsfjord-Elbodalen, hvor den alternerende med brigaden Scharffenberg gjorde forposttjeneste. 
ti! Kl 2. Skrev Breve, gik hen til Capitainen $\mathrm{Kl} \mathrm{7,} \mathrm{han} \mathrm{havde} \mathrm{alle-}$ rede holdt Krigsraad paa Kroen, saa jeg slap meget nemt. Gik saa hen paa Hovedvagten til Jean Hansen, han er paa Vagt hver andet eller tredie Døgn. Her var aldeles ingen Ro. Døren gik 100 Gange hver Time. Barriereportene ere nemlig lukkede og Ingen maa passere uden Commandantens Tillarlelse, hvorfor Aflosninger af Forposterne, ud og indmarcherende Afdelinger etc, maa staae og gloe timevis, da de i Reglen ingen Tilladelse have og derfor først maa sende Bud til Commandanten efter en saadan, det er en ganske vittig Indretning.

29. - Mer Exercits samt I)istancemaaling. Om Aftenen L'hombre hos mig med Dencker, Jelstrup og Jean Hansen.

\section{Marts.}

1. - Vi stille nu om Morgenen Kl $8 \frac{1}{2}$ istedetfor 7 , hvilket jo er en stor Gevinst. Jeg havde i Formiddag ikke meget at bestille, da mit meste Mandskab var paa Vagt, og paa Arbeide saa jeg kun havde $\mathbf{1 0}$ Mand tilbage. Disse lod jeg gaae ud 1 Terrainet for at skridte Distancer af og de fik saa Lov til at gaae hjem kl 12. Selv maatte jeg med 2 Mand blive derude til Kl henad 3 for at modtage muligvis kommende Transporter af Ammunition. Det er Alt andet end morsomt at gaae derude og alte i Skiclt hele Formiddagen for at vente paa Transporter, der i Reglen blive borte, og saa er det ovenikjobet Noget som enhver Inderkorporal kuncle besorge accurat ligesaagodt som en Officer. Det er græsligt hvor man bliver søvnig af den Tjeneste, det gaaer hver Dag saaleiles, at saasnart jeg kommer hjem fra Skandserne lægger jeg mig paa Sengen og sover strax, indtil Jens kommer og spørger om jeg ikke vil hen at spise til Middag.

2. - Kl. 41/2 Morgen kom Commandersergeanten ind til mig og anmodede mig om at staae op da der skulde stilles kil 5 . Hver Mand skulde staae ved Kanonerne i Skandserne Kl 6, da man ventede et Angreb. Saa nu er de da gale igjen sa'e jo jeg, og det var jo ogsaa meget rigtigt. Vi stillede og afmarcherele, men kom ikke længere end til Kongens Port, her maatte vi ikke komme ud. Befalingen var fra Commandanten, ifolge Ordre skulde vi have Kanonerne klare til Skydning Kl 6, men ud af Porten kunde vi ikke korıme. Denne Eventualitet var jo forudseet, Capitainen havde sendt Ordonnants til Commandanten for at faae Ildgangsbillet, der blev svaret at Vagten havde Ordre til at lade os passere; men da vi kom til Kongens Port var der ingen Ordre kommen, og vi maatte derfor igjen med Orilonnants til Commandanten. Saaledes ventede vi nu vell Porten til Kl. 6 $1 / 2$ da Tilladelsen endelig ankom. Det er ganske vittigt indrettet, men denne Vittighed gaaer igjennem clet Hele, saa man tilsidst er 
nær ved at blive gal af bare Vittighed. Det denne Commandant kan hitte paa gjør man sig ingen Idee om. Naa vi kom da endelig ud tilligemed alle de andre Afdelinger der stode ved Porten og ventede og Kl 71/2 var Alt klar ved Kanonerne, det var jo rigtignok 1/2 Time for seent, men forresten tidsnok, da det naturligvis ikke var andet end Gjøgl det Hele, Preusserne tænkte paa alt Andet end paa at angribe Byen. Vi stode nu og glædede os med at vente paa den imaginaire Fjende til KI 1 og havde rimeligvis faaet Lov til at staae der hele Dagen hvis vi ikke havde sendt Bud til Byen for at faae at vide om det nu ikke kunde være nok. Det var den største Del af Dagen rart Sneveir, og da jeg som bekjendt ved min Skandse hverken holder Blokhus eller Barakker stode vi altsaa paa aaben Mark eller paa Gaden fra 5 Morgen til 1 Middag aldeles til ingen Nyṭte. Naar det er det man kalder for Krig saa er det slet ikke saa interessant som man i Almindelighed udmaler Feltlivet og vi ville tage os høist sørgelige ud hvis vi bleve tegnede af i Ill. Tirlende. Kl 3 stillede jeg Vagtparaden og lod den afmarchere og gik da selv ud Kl 4 for at tilbringe 24 Timer paa Vagt. Men da jeg kommer derud er der ingen Afløsning kommen, Vagtcommandeuren og Mandskabet der erc derude ere lynende gale fordi de ikke ere blevne afløste; jeg gaaer da tilbage og møder Vagten ligeudenfor Porten, de have maattet staae i $1 \frac{1}{2}$ Time paa Gaden for at vente paa Tilladelse til at komme ud af Porten. Det bliver dog snart for galt 100,000 Soldater ${ }^{22}$ ) kunne gaae ud og ind ad Porten, naar de ikke ere under Commando, men vil bare en Patrouille bestaaende af 1 Mand og 1 Gefreiter ud skal den først have Tilladelse fra Commandantskabet. Men Califens Ord er Visdom. Lader os ikke snakke eller raisonnere om Ting som vi svage Dødelige ikke kunne fatte og forstaae. Jeg fik dem altsaa afloste derude $i$ Skandserne og de benede jo af for at komme ind $i$ Byen før $\mathrm{Kl} \mathrm{6}$, thi efter den Tid havde der slet ikke været Tale om at de havde faaet Tilladelse til at slippe ind. Jeg æltede nu omkring derude til det blev morkt, der kom et Compagni af 14de Bataillon derud paa Vagt, de ere komne hertil for et Par Dage siden, den sidste Dag de vare $\mathbf{i}$ Kjøbenhavn fik de Geværer udleverede, Minierifler, ${ }^{23}$ ) som de aldeles ikke kjende, de have aldrig for seet den Slags Geværer, de vidste ikke hvorledes de skulde lades, men vilde tampe Kuglerne fast o. s. v. det bliver vist en elegant Skydning de Karle stille op. Der var 3 Officerer med, Compcommand, og 2 Lieutenanter. I Blokhuset i $\mathrm{Nr} 3$ hvor jeg skulde opholde mig blev jeg belemret med en Deling Infanteri, tilligemed Compcommandeuren og den ene Lieutenant. Compcommandeuren satte sig paa en Stol og Lieutenanten delte mit Leie i Halmen, men sove var der ikke Tale om,

22) Naturligvis en kraftig overdrivelse; der var på den tid ialt 12,000 mand i Fredericia.

23) En forbedret slags rifler. 
thi disse forlomte Infanterister sang først langt ud paa Natten og Resten af Natten morede de dem med at gjøe, miave og gale, saa at der var et saadant Spectakel at det var umuligt for mig at sove.

3. - Paa Vagt tilbragte jeg nu Tiden til Kl 3. Jeg havde aldeles Intet at bestille saa Tiden faldt mig temmelig lang, jeg havde glemt at tage en Bog med derud. Jeg horte at vi igaar havde fanget 33 preussiske Husarer, det er jo et ganske godt Coup, de nærmeste Omstandigheder længes jeg meget efter. Endolig horte jeg at Folkene skulde indqvarteres i Barakkerne, hvilket jeg imidlertid ikke vilde troe da kun ganske enkelte af dem vare nogenlunde farlige, men det var dog sandt. Folkene kom virkelig herud og matte ligge i de halvfxrdige Barakker paa en Smule Halm. Kl 3 blev jeg endelig aflast, men kom naturligvis for seent til Byen til at kunne spise hos Riemenschueicler, hvorfor jeg maatte spise paa liroen, hvor man fik Arter og Flask for 3 Mark. Jeg var naturligvis rarlsomt søvnig og gik derfor i Seng Kl 8\%.

4. - Livet er jo temmeligt ensformigt herovre, saa at let er vanskeligt at faae nogen Afvexling $i$ en Daghog. Idag havle vi atter Exercits navnlig for at indøve nogle Infanterister fra Kjobenhavns Garnisonsbataillon, som vi have faaet herover til Hjalp. Om Aftenen spillede jeg L'hombre hos Jean Hansen med Dencker og Jelstrup.

5. - Meer Exercits hele Formiddagen til Kl 1. Commandanten, hvem Himlen bevare, har faaet en ny Idee. Han finder nemlig at det er bedst at 2 Artilleriofficerer ere paa Vagt ad (iangen. Der er a ldeles In te t at bestille for 1 Officeer og naturligvis mincle for 2. Der er bleven gjort ham levende Forestillinger i den Retning for at overbevise ham om det Vanvittige i den Idee, han lorl Verlkommende snakke ud og bemærkedle saa kun: "I)t or min bestemte Befaling . Jo det er en ganske rask Gut. Den forrige Pladsmajor ${ }^{24}$ ) hekæmpede en Dag noget aldeles Vanvittigt i een af hans Ordrer, og kom saa til at sige: „Ja men kjære Hr. General«, hvortil Commandanten jo øieblikkelig svaredle: "Jeg er ikke kjære, jeg er General“, næste Dag fik Pladsmajoren sin Afsked. Naa i Anledning af Commandantens Witz maatte jeg trakke ud i Lejren paa Vagt idag igjen. Der bliver nu hver Dag værre, der er nu snart aldeles bundløst ....

6. - ..... Da Klokken var næsten 4 fır jeg kom op i min Kant af Byen kunde det jo ikke hjælpe at gaae til Riemenschneiders hvor der spises Kl. 2. Jeg gik derfor paa Kroen og ventede her en Stund, endelig gik man til Bords, men saa var der ikke spor af Plads til-

24) Den officer, der skulde gå kommandanten til hånde, navnlig i den indre tjeneste. 
cvers, saa at jeg ikke fik nogen Middugsmad den Dag. Om Aftenen spillede jeg L'hombre hos Jelstrup med Filiger og Rasmussen ......

7. - Idag tjente jeg lidt Tid om Formiddagen ved at give Folkene Accordarbeide ${ }^{25}$ ), hvorved de bleve færdige Kl 11 . Kl 3 trak jeg paa Vagt, hæs er jeg som bare Fanden, for ikke at blive for varm havdle jeg ladet Jens tage min Feltkappe og Taske og havde selv kun min ty̆nde Regnkappe paa, men da jeg endelig kom ud til Skandsen var jeg aldeles drivvaad baade udvendig og indvendig, Veien derud er nemlig frygtelig anstrængende ....

8. - Da det stadig er saa listigt indrettet at man skal have Vagt og exercere etc. med sine Folk i Skandserne paa samme Till maatte jog Kl 9 over til min Skandse. Her bekladte vi Brystrærnene videre. Folkene fik Accord, ligesom igaar og $\mathrm{Kl} \mathrm{101/2}$ vare vi næsten færdige (la Oberstlieutenant Holm og Captainen (Schmidt) kom og saae paa Arbejdet; men bedst som de staae falder der Skud, og ved nærmere Fftersyn fandt vi at det var fra et af vore Feltbatterier der stod en god Fjerdingvei borte fra Skandsen hen atl Stoustrup ${ }^{26}$ ) til og chargerede [beskod vedholdende]. Vi havde ingen Allarmering hort eller Nogetsomhelst, der kunde tyde paa Fjendens. Narvarelse og saa [?] ham nu pludselig kort udenfor Kanonernes Skurlvidlde. Nu var der naturligvis ikke Tale om at permittere Folkene, tvartimod maatte de, der allererle vare permitterede, mode igjen snarest muligt. Jeg maa sige til Folkelies lioes at de moxlte Alle endogsaa 4 Mand der vare syge stillede sirax, kun 3 Mand der laae paa Hospitalet manglede, men de vare jo undskyldte. Naa vi fik jo i en Fart gjort klart Skib og stode fardige tii Skydning. Nu rykkede ogsaa Infanteri og Espingole ${ }^{27}$ ) ud og besatte Leiren og ud til Forstærkning af Forposterne rykkede omtrent Alt hvad der fandtes i Byen. Fægtningen blev en Tid staaende ved Stoustrup, vi kunde baade see og hore vore Folk der vare i Engagement, Fjenden saae jeg derimod ikke, det er vanskeligt at kjende dem fra hiverandre. Efterhaanden trak Fægtningen deels ried ad Erritsø og Snoghøi til, deels Nord paa. Nedle ved Stranden kom Preusserne saa nær ind ved Fæstningen at der blev skudt paa dem fra Volden. Her hænite den Ulykke at en svær 84 Granatkanon med samt sin lappert faldt ned fra Slæ $\left(\mathrm{den}^{28}\right)$ og slog Benene over paa en af Artilleristerne. Idet Skuddlet gik af væltede hele Historien ned af Slæden. I.ige i Begyndelsen af Frgtningen endnu forend vi egentlig vidtste

25) Med udbedring af skansen, se næste dags optegnelser.

20) Lige vest for Fredericia.

27) En slags orgelskyts, der kunde udskyde flere kugler lige efter hinanden.

$\left.{ }^{24}\right)$ Rapert og slædle er kanonens underlag under skydning. 
at der var Fagtning blev General Wilster ${ }^{29}$ ) saaret, en Corporal meldte mig at han havde modt ham da han kom kjørende ind til Byen. Curporalen sagde at han sad og jamrede sig paa Vognen og var haardt saaret, senere sagde Andre at han var let saaret og at han havile sagt til Folk han modte: "Det er Ingenting, jeg kommer strax ull igjen«. Factum var at han havde faaet en Kugle i den ene Arm og var saaret af en Granatstump i Siden, hvorfor han samme Dag blev sendt til Kjøbenhavn. En anden Granatstump havde dræbt hans Hest og slaaet Benet over paa hans stabschef Capt. Hoffmann. ${ }^{30}$ ) Det har nok i det Hele taget ikke været nogen heldig Træfning for os. 1ste Comp af 20 Regiment havde hesat Hønneberg Skov i den Formening at det var Fuglsang Skov ${ }^{32}$ ), de bleve derved afskaarne, drevne ned til Snoghøi hvor Nogle gik $i$ Vandet for at søge at naae Baadene der laae et Stykke ude, men det lykkedes ikke, hele Compagniet med 1 Capitain Daue og 2 Lieutenanter, den ene en Søn af Fru Vincent faldt i Preussernes Hænder. Lieutenant Køhler blev dødelig saaret af en Kugle i Inderlivet. Fra Kysten sendte Preusserne c. 34) Granater over til (let endnu ufuldendte Batteri ved Strib, dog uden Virkning. Henad Kl 12 kom Fægtningen udenfor min Synskreds, jeg saae kun Rogen af de enkelte Skud der faldt fra Volden, men nu begyndte der en levende Kanonare inod Nord, henad Veilekanten hvor den Brigade der laae ved og i Veile 1ste og 11te Regiment etc. var knmmen i llden, Kanonaclen blev ved til det blev markt, hvorledes det or gaaet her har jeg ikke hart noget Nærmere om, men Preusserne rykkele nok ind i Veile $\left.{ }^{33}\right)$. Vi fik selv ikke Fjenden paa Skud, men havde kun Synet. Veiret var hele Dagen mildt og stille. Vi bleve staaende ved vore Kunoner hele Dagen og om Nutten matte vi heller ikke forlade Skanılsen, hvilket paa Grund af dinnes uheldige Beskiffenhed (Mangel paa Blokhus og Barakker) var en meget ubehagelig Tour især da det frøs temmelig stærkt hele Natten. Jeg lagde mig ind i Krultmagazinet, men da jeg ikke havde Halm var der ikke Tale orn at sove, jeg laae paa Betongulvet med 4 Karlatsker til Hovedpude og mine Tæpper over mig, men der var saa haardt at ligge at jeg hvert Øiellik maatte vende mig, og desuden frøs jeg græsseligt om Forderne (vaade Støvler) saa at jeg uagtet jeg heller ikke var i Seng forrige Nat umulig kunde falde i Sovn. Hele Natten var naturligvis rolig.

$\left.{ }^{29}\right)$ Kendt for sin dygtighed og dristighed i adskillige af treårskrigens kampe.

30) Major Hoffman døde på lazarettet efter amputation.

31) Hønebjærg ladegårdsskov ligger lige nord for hoverlvej nr. 1 $3 \mathrm{~km}$ fra Snoghøj, Fuglsang skov gennemskæres af jærnhanen Fredericia-Kolding.

$\left.{ }^{33}\right)$ 1. og 11. reg., der 8. marts kæmpede ved Vejle, som blev opgivet, var som bekendt dem, der standsede fjendens forfølgelse ved Sankelmark 6. febr. 
9. - Kl $5 \frac{1 / 2}{2}$ stod jeg op igjen og jeg lod nu Folkene arbejde for at de kunde holde Varme. Vi satte Distancemærker ud, arbeidede videre paa Bekladningen af Brystværnene og pudsede af, men blive der matte vi jo, da vi skulde kunne vente Fjenden, men der kom ingen Fjende, saa vi stode der og frøs til ingen Nytte. Endelig Kl 4 fik vi Lov til at træde af saa jeg kom ind til Byen $\mathrm{Kl} 5$, i hvilken Anledning jeg idag fik acurat lige saalidt Middagsmad som igaar ....

10. - - ... [N. får kl. 6 morgen besked om, at han skulde have stillet $\mathrm{kl} 4^{3 / 4}$ ! Uventet frieftermiddag]. Min Oppasser var imidlertid gaaet ud i Skandserne og derude var min Madkurv mine Sengetæpper, Slobrok og Morgensko. Jeg benyttede Eftermiddagen til Brevskrivning, men Kl hlev 8 , der kom ingen Jens, og da min Madkurv var i Skandserne maatte jeg hen paa Kroen og spise til Aften, hvilket forresten ikke tiltaler mig, da der altid er en Atmosphære, saa at man er nxrved at quales. Jeg kom hjem Kl 10, der var ingen Jens kommen, mine Sengetxpper laae i Skandserne, thi maatte jeg ligge med de bare Lagener og min vaade Feltkappe, men frøs høist meget saa at jeg næsten ikke kunde sove.

11. Stillede i Skandsen Kl 5\% hvilket paa Grund af min Paaklædthed og Mangel paa Søvn gik meget nemt. Det viste sig nu at Jens aldeles ikke havde været derude. Jeg mente at han var gaaet derud og var kommen til Porten efter Lukningen og saa at han ikke havde haft saa meget Omløb i Ho'det at han kunde bede Vagtcommandeuren om Passerseddel. Men Manden havde drukket sig fuld paa Veien derud og havde saa ikke været hjemme hele Natten. Endnu i dette Øjeblik Dags Middag Kl 2 har jeg ikke seet ham, saasnart han viser sig venter der ham en Tour i Hullet, det er 4de Gang han har drukket sig pærefuld ved Middagstid. Da jeg gik fra Middagshordet kjøbte jeg mig et halvt Rugbrød til 4 Skilling, og dinglede saa af for at gaae paa Vagt, men da jeg kommer til Kongens Port mødte jeg Petri og Larsen, der kom af Vagt, og de meldte mig at jeg ikke skulde paa Vagt... - Naa jeg dinglede op til Jean Hansen, hvem jeg forærte mit halve Rugbrød, og om Aftenen spillede jeg L'hombre med ham, Albeck og Dencker. Jens viste sig heller ikke til Aften. Lars bragte heldigvis uopfordret mine Tæpper hjem.

12. - Da jeg i Dag stod paaklædt Kl 5 kom Jens endelig, forresten æltede jeg som sædvanlig i Skandseskidt til Kl 12...

13. - .... Forresten gaaer Alt saa ensformigt saa at det ikke er værd at spilde Blæk og Papir paa.

14. - Dags Morgen meldte jeg mig syg for muligviis ved at blive hjemme et Par Dage at blive af med min Forkjølelse. Jeg laae derfor meget gemytlig i min Seng kl 10, da der bliver blæst Allarm. 
Skjøndt jeg var temmelig overbevist om, at det ikke var andet end Gjøgl kunde jeg dog naturligvis ikke blive liggende i Sengen, men skyndte mig op og æltede ud til min Skandse. Men det Eneste jeg her saae til Fjenden var at noget Artilleri passerede Nord paa $\mathbf{3} / \mathbf{4}$ Mil borte. Vi stode nu der og gloede $\mathrm{i}$ en frygtelig storm til K1 $2 \%$ da vi dinglede hjem igjen.

15 - Meldte mig atter syg, denne Gang med storre Held. Vejret var ogsaa aldeles ikke skikket til at foretage Nogetsomhelst, da det var en frygtelig Storm, og Regnen pidskede ned uafbrudt, her er i flere Dage formedelst Stormen ingen Post kommen over. Jeg brugte Tiden til at tegne mig Orienteringskort over min Skandse etc forresten skete der aldeles Intet af nogensomhelst Interesse.

16. - Trak paa Vagt Kl 3. Der kom Ordre til at have Kanonerne ladet med Kardætsker om Natten. Jeg sov forresten i Ro hele Natten.

17. - Stod i Allarmstilling fra $5-7$. Kl $9 \frac{1}{2}$ blev der igjen allarmeret, da der viste sig Colonner udenfor Treldesknven. De satte clem fast i Christineberg, en Gaard ved Udkanten af Skoven, men bleve snart fordrevne ved 8 Granater fra Skandserne 1--2-3. Gaarden blev skudt ibrand og nedbrandte aldeles. Forresten viste der sig Intet den Dag (saavidt jeg husker) men vi maatte dog staae i Skandserne til det hlev markt, og $1 / 3$ af Mandskahet maatte blive Natten over.

18. - Intet passeret.

19. - Stod i Allarmstilling hele Dagen da der viste sig stærke Colonner til alle Sider. Forposterne vare i Engagement hele Dagen, fra Skandserne fyredes ikke, vi stode kun og saae derpaa.

20. - I Løbet af Natten havde Fjenden kastet 5 eller 6 Batterier $^{34}$ ) op $i$ en Afstand af c. $4000 \mathrm{Al}$. fra Fæstningen og den forskandsede Lejr. Ved Daggry begyndte han herfra sin Ild. Granater og Brandgranater regnede ned over Byen, hvorfra snart Luerne sloge iveiret, og det var saagodtsom umuligt at faae slukket, da de brændende Steder bleve overoste med Granater. Heldigvis saaredes ikke Mange inde i Byen. Et af de forste Huse der kom i Brand var Garnisonshospitalet, hvorfra man dog heldigvis fik de Syge og Saarede uskadt reddede. Skandserne bleve ligeledes overøste, kun min Skandse Nr 5 blev forskaanet. Jeg fik kun 2 Granater, og Ingen af dr:m sprang. Da clen første var falden, gik jeg ud for at see efter den, men fandt den ikke, da jeg gik tilbage faldt den anden, ikke 1 Skridt bag mig, lige i Nærheden af hvor den anden var falden. For-

34) Skal være 5 . 
resten havde jeg ingen Ulempe af dem, men havde kun den Frgrelse ikke at kunne naae Fjenden, jeg gjorde 2 Skud ud mod Batteriet, men da jeg desværre ikke kunde naae dem opgav jeg det. I Skandserne 2-3-4 regnede de formelig ned. I Nr. 3 fik de den Dag 104 Granater ind i Skandsen, een af dem saarede 3 Infanterister meget let, ellers gjorde de aldeles ingen Skade. Granaterne springe først $i$ Anslaget og Farten driver da i Reglen Stumperne ned i Jorden, komme de $\mathrm{i}$ blød Jord springe de slet ikke. I $\mathrm{Nr} 2$ blev en Constabel dræbt, forresten skete der i hele Leiren ingen Ulykke. Leiren vedbleve Preusserne at beskyde til det blev mørkt, Byen blev beskudt hele Natten. KI 7 permitterede jeg $2 / 3$ af mit Mandskab $1 / 3$ maatte som sædvanlig holde Vagt hele Natten. Der blev sagt at Capt. Schjønning af $13 d$ e Regiment var bleven dræbt, men det reducerede sig heldigvis til at hans Hest var skudt under ham.

21. - Fra Kl 3 Morgen beskjødes Leiren igjen. Byen var beskudt hele Natten og Bombardementet vedblev irlag. Ved Middagstid heisedes Parlamentairflag paa de fjendtlige Batterier, Skydningen ophørte, og en Parlamentair kom ind og forlangte Fæstningens Overgivelse. Da der naturligvis blev givet bestemt Afslag begyndte Beskydningen atter og vedvarede til Aften. Skandserne havde i Løbet af Natten faaet svært riflet Skyts ud, da man ikke kunde naae de fjendtlige Batterier med de gamle Kanoner. Fra $\mathrm{Nr} 4$ hvor der havdes 1 riflet $12 \&$ Kanon sendtes nu det ligefor beliggende Batteri 8 Skud der alle sprang i Brystværnet og Skydeskaarene paa det fjendtlige Værk og opvakte endeel Forvirring saa at saalænge Skydningen fra $\mathrm{Nr} 4$ varede skjøde Preusserne meget slet, men da vi ikke havde megen riflet Ammunition, da det var vanskeligt at ødelægge Fjendens Batterier paa saa stor Afstand og da Tydskerne dog ingen Skade gjorde med deres Skud og da vi endelig for hvert skud fik $6-8$ igjen opgaves Skydningen som unødvendig. Preusserne vidste nu dog at vi kunde naae dem. Fra en Skandse i Nærheden af Treldeskoven beskjøde Preusserne Skandserne 1 og 2 med runde Granater, der dog aldeles ingen Virkning gjorde da den største Deel sprang $\mathbf{i}$ Luften 4-800 Alen foran Skandserne. De Granater der sendtes fra de andre Batterier vare Spidsgranater, der sprang i Anslaget. Ikke een Mand blev saaret skjøndt Preussernes Spidsgranater traf udmærket. Inde $\mathrm{i}$ Byen regnede Granater og Brandgranater ned ligesom den foregaaende Dag, een Granat slog Hovedet over paa en Infanterist, rev Hjertet ud af en Anden, Bagdelen og Nyren aí en 3die begge Benene af en $4 \mathrm{de}$ og saarede en 5te, ellers var Antallet af Dræbte og Saarede heldigvis ringe. Naturligvis flygtede Alt ud af Byen og Husene blev tildeels ladte aabne for Plyndring. Dette benyttede Soldater og Brandfolk sig da ogsaa af. Men de gik ikke allene ind hvor der var aabent, men gjorde ligefrem Indbrud, hos mig 
stjal de dog kun mine Cigarer, Tobak, Regnkappe, Lygte, Caffekande, Sæbedaase, Børste etc desuden min Oppassers Tøi, de brækkede Døren til min Værts Klædeskab og Spisekammer op og toge hvad der fandtes. Hos en Capt. Christensen i.Ingenieurcorpset brækkede de ind og toge hans Uniformer og Alt hvad de kunde faae, skjøndt hans Oppasser var hjemme og protestererle. Ja, hos en Læge stjal de Medicinen, Forbindtasker, Cantinetornyster ${ }^{35}$ ) kort Intet blev urørt. Men der var naturligvis ikke Tale om at stjale eller røve, nei, man red. (lede blot. ${ }^{36}$ ) - Efter Parlamentairens Ankomst og i Anledning af at det imorgen er Kongen af Preussens Fødselsclag ventede vi Angreb inat, i hvilken Anledning vi matte staue ved Kanonerne hele Natten, efter at have staaet der hele Dagen.

22. - Dagen hengik meget rolig. Intet rorte sig. Ved Daggry saae man Ild bag de fjendtlige Skandser og det viste sig senere at det var deres Barakker som Preusserne havde brændt af. Stor Forundring, hvad skal det sige? Men det viste sig at Preusserne havde virkelig forladt Stillingen, alle Batterierne vare forladte, det ved Treldeskoven blev sløjfet af et Arbeidscommando fra $\mathrm{Nr}$ 1. Dagen hengik aldeles roligt. En forunderlig Ro, ler havde noget Aparte ved sig, disse 2 Dages uafbrudte Bombardement, Opfordringen til Overgivelse, og dernæst fuldstændig Forsvinden. Ingen kunde fatte det. En Mængde forskjellige Rygter kom jo i Omløb: Ved Bogense laae en stor engelsk Fladde, Svinskerne vare landsatte i Fredericia, der var gaaet ind pua Conferensen og Tydskerne skulde forlade Nørrejylland, det. Artilleri og Infanteri var rykket ud af Fæstningen for at følge Preusserne til Kolrling o. s. v. Desuden havde der den forrige Nat været heftig Skydning Nord for Erritsø, paa et Sted hvor der ikke fandtes en Eneste af vore Tropper, saa at rimeligvis Wsterrigerne og Preusserne have været i Haarene paa hinanden. Men tryg var man ikke. Jeg benyttede den gorle Leilighed til at tage alle Skandserne $i$ fiesyn. Ingen af dem havde lidt noget, naar man undtoger at nogle Granater vare gaaede igjennem Baricaderne etc. Dernæst gik jeg ind og besaae Byen; den saa værre ud. Hele Gader nedlræncte. Tage og Mure gjennemhullede, hele Ruder en stor Sjeldenhed, dog var det kun eet Qvarteer, nemlig i Nærheden af Prindsens Port ${ }^{37}$ ) der havde lidt saameget. Landsoldaten stod dog endnu, skjøndt de omliggende Bygninger havde lidt meget. Det er nu ikke muligt at opdrive Noget $i$ hele Byen, hverken af den ene eller anden Slags. Varst er det at man ude i Leiren ikke kan faae Andet at dicin.

s5) Tornyster med kasse til forbindstoffer, instrumenter og me-

${ }^{36}$ ) Det var kun enkelte soldater, der "reddere" undres ejendele. Gennemgående var troppernes holdning under bombardementet fortrinlig.

$\left.{ }^{37}\right)$ I nordvest ved Landsoldaten. 
drikke end noget meget daarligt Vand i Reglen Regnvand fra en af Lobegravene, da dette er det bedste, naar man skummer det Tynde ovenaf. Min Oppasser som jeg igaar sendte ind efter Cigarer og Tolak fik efter miegen Mrxie 16 Cigarer til 1 Mark og $1 / 2 \mathbb{E}$ Tobak til 12 Skilling! Da han irlag var inde i Byen reddede min Oppasser min Regnkappe. Han morlte nemlig en Trainconstahel der nok saa flot spadserede i den, nien Jens kjendte strax Kappen og fik den halet af ham og kom ud med den i Triumph. I) jeg var inde i Byen traf jeg Jean Hansen der boede i et Halmskuur, medens Anclre havde gravet de $m$ Huler ind i Volden. Brigadeadjudanten Irminger fortalte mig at vi nok kom til at staae i Skandseme inat og meget rigtigt, da jeg gaaer ud morler jeg Capitainen, der fortwller mig at hele Banden ifjen inat skulde staae ved Kanonerne, da man meente at det var en Finte af Fjenden og da man havde faaet sikker Efterretning om at hele Omegnen var belagt med Gsterrigere. Naa, det var jo en glædelig Tidende, men der hjalp nu ikke noget, vi maatte staae der og stode der ogsaa.

23. - Hele Natten gik uden Forstyrrelser, i Morgenstunden fuldt nogle enkelte Geverskud ude fra Fuglesangskoven, ${ }^{38}$ ) men hertil indskrænkede Fjendtlighederne sig, vi saae i det Fjerne 2 østerrigske Dragoner, men forresten Intet. Jeg henyttede Tiden til at male i min Daghog. Der kom idag Orlre at hverken Capitainen eller nogen af Lieutenanterne maatte forlade Leiren. Byen er altsaa nu lukket for cs. Det er een af de sardvanlige vittige Befalinger, der daglig komme. Det er nu ikke fordi der er morsomt inde i Byen, men man kunde dog engang imellem faae en Avis at see, nu gaaer det ikke mere...

24. - ... Vi fik Efterretning om at Kongen vilde komme imorgen eller senere og fik nu travlt med at gjøre reent og pænt til hans Ankomst, forresten er det en løierlig Tilværelse $i$ disse Dage, denne complette Ro ovenpaa de 2 Dages uafbrudte Bombardement, man tager sig nu og da en Luur og bestiller forresten Intet.

25. - Vi have det nu efter Omstændighederne meget ordentligt. Vi ere 4 Artilleriofficerer sammen, der i Reglen, det vil sige i denne

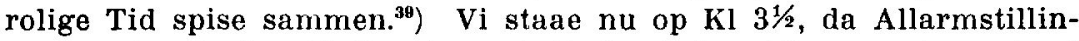
gen er fra 4-6. KI 8 spiser vi Frokost, hvortil er reglementeret Boeuf og Speilæg, der laves af Lieutenant Larsens Oppasser. Desuden have vi jo alle de rare Sager der findes $i$ de herlige Madkasser, som velvillige Mennesker ere saa gode at sencle os. ${ }^{40}$ ) ... Idag stod jeg i Skandsen ifølge Ordre fra $\mathrm{Kl} 3$ for at vente paa Kongen, men han kom først til Fredericia Kl 9 Aften og kom derfor ikke til

${ }^{38}$ ) Se meddelelserne for 8./3.

${ }^{39}$ ) I anledn. af, at de ikke må komme ind i byen, jvf. ovenfor.

40) I samme anledning. 
Skandserne. Veiret var udmærket. Jeg har nu faaet mit Mandskab temmelig completteret med civile Folk. Mit Mandskab seer nu temmelig løierligt ud, jeg har deels Folk i Uniform, nogle Rekruter, Andre aldre, Andre temmelig gamle, en Væagteruniform sees ogsaa da jeg har faaet blandt de sidst indkaldte en Frederiksberg Vagter, der er mult i Iniformen, endvidere har jeg Infanterister og saa civile Folk af høist forskjelligt Udseencle. Forresten kommer jeg udmarket ud af det med dem Alle og Alt gaaer med det Gode.

26. - Op Kl $3 \frac{1}{2}$ og fik min Skandse meget fiint pudset. Dernest spiste jeg Frokost, 6 Mennesker gnavede paa min Kapun og glade vare Alle. Ved Frokosten fik jeg Telegram om en ny Madkurv, i hvilken Anledning man straks udbragte et Leve for de ædle Givere. Kl 10 kom Kongen til min Skandse. Jeg havde anbragt mine ulykkelige Civilister saa iøinefallende som muligt og da jeg havde hilst paa Kongen og han havde erkyndiget sig om mit Navn og Befindende gik han op til Civilisterne klappede og spurgte, hvorledes de havde det og hvorlænge de havde været i Tjeneste. Da de bemærulykkelige Civilister saa iøinefaldende som muligt og da jeg havde sagde han til Krigsministeren:41) "Jeg saa hellere at Uniformerne kom før Mandskabet«. Den kunde jo Krigsministeren putte i Lommen, men det er ogsaa en Skandale at lade disse Stakler gaae her uden Klæder, sove uden Tapper etc. Det er iclag complet Sommerveir, Roligheden vedbliver at være uforstyrret. Den Eneste, der brolede Hurra for hans Majestæt var den berommelige Hansen i $\mathrm{Nr}$ 3. "Længe leve hans Majestæt Kong - Christian d. IX" han kunde ikke rigtig huske hvad Kongen hed, men pauserede efter Kong....

27. - . [Nørgaard er med ude at sløjfe fjendtlige batterier. Det er hans faders fødselsdag.] Vi hørte derude at den første Dag havde Preusserne hoveret, fordi vi ikke kunde naae dem, men de bleve meget forbavsede da den næste Dag den ene Granat efter den anden susede dem om Ørerne og endogsaa dræbte 1 Mand 800 Alen bagved Batteriet. Den 22de Morgen Kongen af Preussens Fødselsdag skulde der stormes, men Soldaterne stak deres Bajonetter i Jorden og vilde ikke gaae frem. Der rykkedes derfor tilbage men Preusserne sagde at nu kom Østerrigerne, de skulde nok gjøre Kaal paa Fredericia. Det er en Udtalelse som Preusserne jo egentlig ikke have megen Fre af... Da jeg endelig kom hjem efter megen Anstrengelse, det regnede hele Dagen, og disse pløjede Marker vare derfor lidt tunge at gaae paa, fik vi os et godlt Foder. Min Paaskemadkurv kom netop tilpas og i den Xeres der medfulgte blev gjentagne Gange den Gam-

11) Lundbye. 
les Skaal drukket. Vi drak og sang og sang og drak til kl var 10 som er den seneste Tid paa hvilken vi her gaae i Halmen.

28. - Irlag var det et afskyeligt Veir. Der var atter Arbejdskommando ude for at sløjfe, men jeg vogtede mig nok for at dingle derud igjen. Roligheden blev uforstyrret hele Dagen (o. s. v.)

29. - ... Vi hørte nu at Preusserne igaarmorges havde prøvet paa at overrumple Dybholstillingen, men at de vare slaaede tilbage paa det kraftigste, hvilket naturligvis animerede Stemningen betytdeligt. Endvidere kom en Snees osterrigske ${ }^{42}$ ) Husarer, der vare fangne af 100 Mand af 19de Regiment $i$ en Landsby ${ }^{42}$ ) ved Vejle, hvor de vare overrumplede om Natten, dette satte ogsaa Humeur i Folk og saa fik vi Efterretning om at Østerrigerne havie kjørt 24 is's riflede Kanoner gjennem Kolding. Er dette sandt faap vi det vel snart varmt nok, men dette Liv vi nu fører er ogsaa for kjedsommeligt i Længden. Forresten er det Hele temmelig ufatteligt, thi igaar kom Posten hertil fra Kolding aldeles uhindret, medens denne Vei nu i lang Tid har været spærret. Folkene længes ogsaa efter at komme til at prøve deres Kanoner. Der gaar i ovrigt mange Rygter her, at vi skulle til Sønderborg, ja til Kjøbenhavn. Jeg skulde nu til at sende mine tomme Madkar hjem, men hører nu at conmandanten har forbudt al Udforsel, paa Grund af Soldaternes Roverier....

30. - [Intet af interesse].

31. - De 22 Husarer der bleve fangne forleden nappedes nok paa folgende Maade. Capt. Stockfleth ${ }^{\text {t3 }}$ ) der var ude med 100 Mand kom pr. Transporthaad til Nærheden af Veile, ${ }^{4}$ ) for at komme gjennem Fjendens Kjade lrugte de folgende Fif. Han lod Folkene gare paa Kjæde men blev selv tilhage med en Hornblæser som han gav Ordre til at blæse alle mulige Signaler, hvorved han fik Fjenden til at troe at der var en ryslig Hoben Mennesker. Han havde faaet Inderretning om at en Landsby i Nærheden af Veile var belagt med preussiske Husarer. Thi gik han ind i Landshyen i al Stilhed omringede en stor Gaard, gik ind og opfordrede Husarerne til Overgivelse fortællende dem at 4000 Mand stode udenfor. Paa den Maade tog han de 22 Husarer og $23^{45}$ ) Heste der fandtes paa Gaarden og korn lykkelig og vel afsted med sit Bytte. Imorges var en Patrouille paa 30 Mand urle for at recognosere Terrainet, de tog 1 Sergeant og 3 Mand tilfange, en I'ndercorporal skjol en Hest under en Husar, men IIusaren, der var paa Landevejen medens Indercorp. var paa en ploiet

2) Skal vere preussiske.

42) Assendrup $10 \mathrm{~km}$ 11. ø. for Vejle.

43) Faldt ved Dybbøl 18./4.

44) S. landsatte styrken i Sandbjerg vig nord f. Juelsminde.

45) Skal vare 24. 
Mark, løb fra ham. Det mest Comiske var dog den Enes Tilfangetagelse. Han blev taget af en af Vore paa følgende Maade. De nærmerle dem hinanden meget forsigtigt paa 20-30 Skridt, saa fyrede Jens, men feilede. Han blev flau og havile stor Lyst til at stikke af og puttede Ho'det mellem Benene, da Østerriger'en skjød; denne feilede ogsaa og da han saae det smed han sit Gevær og gav sig til at vræle af alle Kræfter, hvorpaa Jens ligeledes smed sit Gevær og lob hen og tog Østerrigeren i Kraven og ruskede ham ordentlig og tog ham til Fange med det Samme, forresten er Freden uforstyrret.

\section{April.}

1. - Ingen Løier skjøndt det idag er forste April. Her i Leiren hænder der aldeles Intet der er mærkeligt eller værd at optegne.

2. - Idag maatte vi bivaane et nyt Skuespil idet en af mine Folk for respektstridigt Forhold mod en Officer hlev afstraffet med Nedsættelse $i$ de Meniges anden Klasse, i hvilken Anledning Cocarden blev berøvet ham, samt 25 Rottingslag. Det var 2 Corporaler, hver med sit tykke Spanskrør (Rotting) der tilleelte ham dem, men det var slet ikke hyggeligt at see paa. Vi faar os nu en liden I,hombre efter Middagsbordet. Spillebordet er jo ikike af re fineste, da det nemlig er et Stykke af en gammel Dor, som der er sat Been under, men det gaaer dog ganske godt....

3. - Det er idag et ganske afskyeligt Veir. Efter Frokosten Kl \& toge vi os derfor en L'hombre, toge en dito efter Mellemmarl hl 1: og da vi havde spist til Middag KI 4 fik vi en Whist saa at Tiden gik meget ordentligt. Vi sturlere med stor Iver de i Dagbladet varende Correspondancer fra Sønderborg, men beklage stadig ikke at have en slig Referent heroppe, til at beskrive vore Bedrifter med saa glødende Farver, thi noget i den Grad vanvittigt Sludder skal man rog lede længe efter, disse Correspondancer give de tydske Krigslueretninger aldeles Intet efter.... I Iag havde jeg endvidere den Glade at modtage 1 Kasse Cigarer og Daghlarle senclte fra Kjobenhavn den 21. Januar fra Peter, ${ }^{46}$ ) sant Brev, Dagblade og Sangbog senalte den 29. Januar fra Bjerring. Cigarerne vare desverre saa drivvaade at man kunde vride dem. men de kom forresten meget tilpas, da mine egne vare slupne op. Disse Pakker havde altsaa varet 21/2 Maaned underveis, ja det er et Fandens expedit Postvasen, det har jeg stadig sagt. Vi have nu abonnerct paa Dagbladet, irlag fik vi Bladet for igaar, let for iforgaars var bleven borte, sagde man paa Posthuset.

46) Se optegnelserne for $93 . / 2$. 
4. - Imorges var jeg oppe ved Skandse $\mathrm{Nr} 1$ og saae paa nogle Skydeforsøg med Orgelespingoler, det var noget Snavs, det er gamle Musketløb der ere samlede $i$ en Ramme og ladede som Espingoler, 16 Stykker ere sammen, men de skyde meget usikkert .... [Der følger h. a. en skildring af den smukke natur ved stranden]. Jeg hørte idag noget nærmere om den mystiske Skydning bag Erritsø for en Tid siden i Bombardementsdagene. En Lieutenant havde nemlig faaet Brev fra en Proprietair hvis Gaard ligger der i Nierheden. Sagen var nemlig følgende: Der var besluttet en Storm til den næste Dag, Preusserne havde jo bombarderet, saa mente de at det var nok gjort uf dem, de vilde inte storme, og Østerrigerne vilde ikke rage Kastanierne ud af Ilden for de Andre, men bemærkede meget rigtigt, at det de havde gjort var aldeles uden Nytte. Sammen med Østerrigerne vilde Preusserne heller ikke storme, hvorpaa Øster. skjældte Preus. ud for feige Esler, men Storm blev der ikke Noget af. Et Compagni Østerrigere kom nu ned ad Stranden til, men kort efter kom en Afdeling Preuss. og opfordrer dem til at æde deres Ord igjen. Østerr. ville ikke, hvorfor Slagsmaalet begyndte, og de blive ved at skyde paa hinanden i 1-2 Timer. I)tte er efter en saaret "sterr. Inderofficers Forklaring. Den omtalte Proprietair fik Tilhold om at rømme sin Gaard og fylde hele Pladsen med Halm til saarede, Officeren der gav ham Ordren forklarede at det var et Theld, Preusserne havde antaget $\varnothing$ sterr. for Danske, der var'e gaaede i Land og saa havde de skudt paa hinanden. Hvor stort Tabet har været er vanskeligt at afgjore, men der er kommen store Masser af Saarede gjennem Kolding, nogle Beretninger sige endogsaa 3000 Saarede og Døde, hvilket naturligvis er Logn.

5. - Det lufterle idag temmelig stærkt. Schnack ${ }^{48}$ ) og jeg gik en Tour ned til Stranden og saae par Havet i Opror. Det skulde vi imidlertid inte ha'e gjort, thi vi vare uheldige nok til at komme op $i$ noget Valkeler, ${ }^{49}$ ) hvori vi sank. Jeg kom heldigvis strax op, men Schnack arbejdede sig stadig langere ned i Skidtet. Heldigvis fik jeg fat i et Stykke af Bunden af en Baad som han lagde det ene Knæ paa medlens han halede $i$ det andet Been og endelig kom det da ud men saa sad Haanden med et godt Stykke Arm i og korn ikke ud ullen at have mistet en Ring og Gudbevares hvor vi saae ud. Om Eftermiddagen var Veiret bedre og vi gik en Tour derned igjen, men undgik naturligvis omhyggeligt Valkeleersklumperne. Om Aftenen fik vi Underretning om at Preusserne skulle have forladt I)ybbølstil-

48) Den 25-årige sekondløjtnant i artilleriet J. G. F. Schnack er senere især kendt som krigsminister 1896-97 og 1899-1901. Lillebælt.

$\left.{ }^{10}\right)=$ plastisk ler, der træder frem i skrænterne på begge sider af 
lingen. $\left.{ }^{50}\right)$ Skulde det virkelig vare Tilfældet. De ere jo da for bestandig prostituerede. Hvad ville de nu gjøre? Gaae vak eller komme herop igjen -?

6. - Yderligere Oplysning om Sammenhangen ved Dybbøl savnes endnu, Nogle paastaae at Preusserne virkelig ere gaaele tilbage Andre paastaae at det er Logn, da Ilden er begynult igjen, men Ingen veerl noget Bestemt. Her forefalder alieles Intet, hver Lag Exercits, Jorlarbejcle etc. uden Afvexling. Vi gase os i Reglen hver Dag undlertiden to Gange om Dagen en Tour ned til Stranden, det er den eneste Afvexling vi have herude. Da jeg i Eftermiddag laae paa min Sopha a: Sengested, kom en Ordonnants med en Skrivelse til mig frá Commandantskahet, hvori jeg blev opfordret til snarest muligt at mode paa Commanclantskaliets Contoir, da en Sag af Vigtighed for Fæalrelandets Frelse skulde drøftes. Jeg gloede jo noget loierlig paa denne Skrivelse undertegnet Efter Befaling Stephansen Ordonnantsofficeer. Steph. er en af mine Kammerater fra Artilleriskolen. Jeg anede Craad, da det dog vilde vare høist meget mærkeligt om Generallieutenant Lunding skulde ville conferere om Fidrelandets Frelse med Lieutenant Nørgaard. Jeg sendte derfor Ordonnants ind for at hare om det hastede, thi for selv at komme til Byen skulde jeg forst op til Capitainen $i$ den langt bortliggende Skandse for at udbede mig T'illadelse, og det havde jeg ikke Lyst til. Ordonnantsen kommer tilbage med en Flaskekurv med 6 Flasker Viin, samt en Skrivelse. Og hvorledes var saa Sammenhængen? Det var saaledes at Stephansen havde modtaget en Kasse hvori der efter Addr.brevet skulde være Krudt, den var addr. til Stephansen og mig, og han kunde ikke begribe hvad det var. Endelig aabner han og finder at det er 12 Flasker Viin som vor Qvarteervært i Faaborg Grosserer Lund sender os. Det kan man virkelig kalde et Mønster paa en Qvarteervært. Han har naturligvis ogsaa vor fuldkomine Agtelse.

7. - Illag gik jeg til Byen for at ordne nogle Pengesager for de Folk jeg førte herop fra Sønderborg. Endvidere besagte jeg Stephansen, hos hvem jeg laante en Hest og red en Tour med ham i et meget behageligt Veir. Byen ser som sædvanlig meget kjedelig ud. Den staaer endnu omtrent som Dagen efter Bombardementet. Kun ere de bare Mure i Reglen nedrevne, saa at der nu ligge store Grusdynger rundt omkring paa Brandtomterne, istedetfor at man seer de lange Skorstene som truende Udraabstegn pege mod Himlen midt i en rygende Grushob ....

8. - [Kongens fødselsdag] ..... Endnu har man her ikke hørt hvorledes Sagerne egentlig staae ved Dybbøl, idag fik vi jo Under-

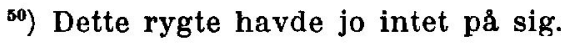


retning om at ved en Forpostfægning 3 Officerer ${ }^{51}$ ) vare faldne det tyder jo ikke paa at de ere borte men paa den anden Side faaer man aldeles ikke at vide hvor den Fægtning har været. En Corporal her har faaet et Brev fra Sønderborg, hvori der staaer at vi have sløifet Preussernes Broagerbatterier, $i$ saa Tilfælde maa de være gaaede langt tilbage, men alle disse modsigende Efterretninger gjør, at man her gaaer i en frygtelig Spænding .... [Tur til stranden, hvor] Solen skinnede saa yndigt varmt og ikke en Vind rorte sig undtagen meget lidt. [skildring af Treldeskov] .... Efter Bordet gik Schnack og jeg over til Nr 2 hvor vi spillede L'hombre med Mathiesen og Petri. Her hørte vi, at i Skumringen havde Østerrigerne besat Veilby og Anelyst ${ }^{52}$ ), formodentlig for at opsnappe vore Morgenpatrouiller, men dette blev ved Meldingen forhindret.

9. - [Driveri er grasseligt], medens de Andre slaaes dernede ved Dybbøl.

10. - Efter Bordet fik vi os en L'hombre, men Kl $7^{1 / 2}$ gik Schnack og jeg hjem .... vi havde netop idlag faaet 2 Kasser Madvarer og 3 Kasser Urtekramvarer til Messen, saa vi maatte jo prøve disse herlige Sager. Det gjorde vi da ogsaa, efter Aftensbordet fik vi os nogle Todlyer og sade nu og sang og opførte Operaer etc. lige til Kl 111/2. Der var et græsselig godt Humeur i os og vi sloge virkelig Gjakken løs gave Scener navnlig Schnack og jeg gav store Arier tilbedste med Orchesteraccompagnement og Folk morede dem udmarket, medens man i Skandsen i Nattens Stilhed kunde høre Kanonernes Torden fra Dybbøl. Imorges afgik herfra 3 officerer med 200 Artillerister til Als. Her mærke vi som sædvanlig Intet til Fjenden, Stillingen bliver med hver Dag stærkere, der arbeides stadigt paa den, man kan nu næsten ikke kjende den mere, nar man har varet en Maanedstirl borte.

11. - Endelig have vi da faaet vore gamle Forstærkningsfolk uniformerede, thi ere de Alle glade. Det er forresten et Fandens Arbejde at faae Tiden til at gaae her om Dagen thi her er jo aldeles Intet at bestille, hvorfor man i Reglen antræffes liggende paa sin Seng lasende $i$ en frivillig Bog eller studerende Dagbladet. - Imorges hørtes her en voldsom Kanontorien fra Dybbol mellem 12 og 3 og i Eftermiddag fik vi jo Efterretning om at Preusserne igjen imorges havde forsøgt Storm paa loegge Fløie, men ere venite om paa Halvveien. ${ }^{53}$ ) At man ikke kunde blive dernede, da man engang var der

$\left.{ }^{51}\right)$ Ved forpostfægtningen natten mellem 5. og 6. april faldt kompagnikommandøren kaptajn E. B. M. Hansen og premierløjtnant F. W. Ravn samt sekondløjtnant $T$. A. Jensen.

$\left.{ }^{52}\right)$ En gård $1 \mathrm{~km}$ syd for Vejlby.

s3) Der forefaldt ikke nogen kamp ud over det sadvanlige ved Dybbøl den dag. 
er virkelig haardt. Capitainen var her til Aften og vi sade saa og snakkede til Kl 11\%2. Vi fik Inderietning om at de 200 Mand vi sendte afsted igaar, kunde ventes imorgen, da der alleredle vare komne 310 Artillerister til Sønlerborg fra kjobenhavn, forresten forefaldt Intet af Betydning.

12. - Siden 1ste April faae vi her Dagbladet og have derved den Fornøielse at læse Correspondancerne fra Sinderborg. Noget saa Vanvittigt og Opskruet skal man have Ondt ved at fincle i en tydsk Avis. Jrg skal herefter tillade mig at Ievere en Commentar til disse Correspondancer. Correspondenten lader til at have kastet sin Kjærlighed specielt over Lieutenant Ancker der ganske vist kan vare en meget hrav Officeer, meget dygtig og tapper, men hvad der anføres til hans Roes er af den Natur at enhver der kjencler en lille Smule til Artilleriet enten siger at det er Logn eller ogsaa levner af Grin over at Sligt bliver omtalt. I een af Correspondancerne staaer der saaledes under 5 April at Ancker, der kun havde 1 Kanon en Tid dominerede Fjendens Ild 10 Kanoner af dobbelt saa svart Caliber som hans, saa at de 10 Kanoner ikke turde binde an med ham $f(i r$ de vare hlevne forstærkede med flere Felthatterier, det er virkeligr storartet, men saa usandsynligt at man næsten maa kalde det Logn. I en anden Correspondance fortalles hvorledes han havde faaet det ene Hjul skudt itu, Reservehjul havde han ikke, de maatte hentes i Sonderborg, hvad gjor saa Lieutenant Ancker, han binder Hjulet sammen og "bum, saa gaaer det igjen paa Stumperne«. Ja see det takker Fanden ham for, thi det er noget enhver Rekrut lærer at na: et Hjul er gaaet itu, saa anlægger man en Besnsring, forskjellig efter Skadens Idstrækning og saa paa den igjen, saa at det virkelig er latterligt at anføre Sligt til Folks Berømmelse. Ien 11te April fortæller Corresp. at da Ancker havile faaet en Kanon demonteret, kjørte han en tom Forstillingskasse op paa Banken ${ }^{54}$ ) og lagde en Bjalke ovenpaa, hvornæst han hele Dagen havile den Glinde at see Preusserne fyre efter denne formeentlige Kanon. Hvad er det dog for noget forbandet Sludder? Preusserne ere saa nwr Skandserne at de lel kumne skjelne en Bjælke fra en Kanon, og selv om de ikke kunde det vilkle det dog være Vanvid at beskyde denne formeentlige Kanon, som de med Lethed kunne indse er uhrugelig da den ikke fyrer og ikke lliver trukken ned af Bænken, som de andre Kanoner, der ikke blive hrugte, thi vi lade ikke Kononerne staae paa Bankene som Skive for Fjendens Kugler naar vi ikke bruge dem. -- Corresp. fortæller den :den Apr. at "Luften krydsedes af hvinende (iranatstumper." I)et er en temmelig mystisk Talemaade. Den 5te fortaller han om vde rode ildsprudende Granater.« Jeg har aldrig seet eller hist Tale om rode

54) ᄁ: kasse på kanonens forvogn op på afsatsen til opstilling af kanonen bag brystværnet. 
Granater og hvad denne Ildspruden angaaer da er det vist en Illusion, da Preusserne bruge Percussionsgranater, der først tænder i det Øjeblik de ramme og derfor have meget vanskeligt ved at flyve omkring og sprude Ild. D. 11te fortæller Munden at en Officeer havde betroet ham at det var kommen saa vidt at han maatte tage til Takke med et Krudtmagazin til at sove i. sic! han udbryder i den Anledning: "En Granat og det Hele gaaer i Luften." Ja Død og Pine paa den Maade kunne vi Alle blive Helte. Medens jeg var ved Dybbøl laae jeg hver Nat i Krudtmagazinet, under Bombardementet her laae jeg ogsaa i mit Krudtmagazin, da jeg skulde være i Skanrsen og det var det eneste Sted hvor jeg kunde sove. Manden skulde trenke paa at Krudtmagazinet er det sikkreste Sted i hele Skandsen, det er hombefaste Betonhvælvinger med adskillige Alen Jord ovenpaa, saa der hører sgu ikke meget Mod til at opholde sig i et saadant Magazin, det er i alle Tilfalde ikke Noget man behøver at prale af $i$ et offentligt Blad. Men Dod og Pine naar vi have en saadan Correspondent her saa kunde der vist ogsaa findes meget her, der var værd at omtale. For Fremtiden skal jeg dog saa vidt muligt søge at oplyse det Vanvittige $i$ disse Correspondancer. Her or der naturligvis aldeles ikke Noget ler er værd at omtale, det gaaer her den ene Iag som den anden.

13. - ... I Eftermiddag diverterede vi os med at spille Pind, ellers more vi os i Reglen ved at synge Arier, hvilket vi gjøre udmærket, kun Skade at vi ikke have en Guitar eller et landet herligt Ingstrument til at accompagnere vore store Nummere. I dette Øjeblik kom Folkene tilbage, som skulde have varet til Als. ${ }^{55}$ )

14.-17. - Intet $\mathrm{Nyt}$.

18. - Idag fik vi Kl 2 Telegraphdepeche fra Sønderborg $» K l ~ 10 \%$ almindeligt Angreb over hele Linien." Ikke et Ord mere, vi gik derfor naturligvis meget spændte til Kl 5 da en ny Depeche meldte at Dybbolstillingen var stormet, og et Par Brigader gaaede i Labet. Det var jo et frygteligt Slag. Stemningen blev naturligvis gruelig nedtrykt, navnlig da Depechen var affattet saaledes at man ikke kunde gjøre sig noget Begreb om Ulykkens Udstrækning.

19. - Idag fik vi da noget nærmere Underretning men det var rla egentlig kun en Liste over endeel af de døde, saarede og fangne Officerer. Listen var lang, den var meget lang men det var desværre kun en lille Deel af det Hele. [Ontale af nogle Norgaard bekendte sårede] ....

20. - Idag horte vi da endelig at vore Folk have slaaet godt; det der nemlig mest trykkede Stemningen var navnlig det at man meen-

so) Jvf. optegnelserne for $10 . / 4$. 
te at vore Folk vare aldeles overraskede saa at der ingen Modstand var gjort, men Alt var løbet tillage pèle-mèle, men da vi nu hørte, at 9de og 20de Regiment, der nylig havde været her i Fredericia, havde generobret Skandserne ${ }^{5 t}$ ) med stormende Haand, og kun havde veget for den frygtelige Overmagt, og i gorl Orden havde trukket sig tilbage, da vi hørte dette svandt det bittre Indtryk vi havde faaet af Affairen da jo nu dog Eren var reddet. Idag spiste jeg til Middag inde i Byen hos Jelstrup og hans unge Kone, der er nydelig. Efter Bordet fik vi os en L'hombre og om Aftenen drak vi vore tappre Kammeraters Skaal ude i vor Barakke.

21. - [Intet af interesse.]

22. - Store Bededag. Den Correspondanceartikel der staaer i Dagbladet af 21de er i mange Punkter saa utrolig at man maa forskrækkes over at noget Sligt kan skrives....

23. - Idag fik vi ligeledes Merddelelse om at Preusserne ere paa Veien, ja nan forsikkrer enclog at de have besat de omliggende Byer Veilby, Igum, Igeskovis) etc. Vi skulle være forberedte paa Alt.

24. - Der viste sig ikke Spor af Fjendtlighedler.

25. - Ligesaalidt.

26. - Jeg var idag en lille Tour i Byen for at blive photographeret, da mit Mandskab havde anmodet mig om det samt om Tilladelse til at kjøbe mine Portraiter hos Photographen. Jeg blev naturligvis saa rort over denne Anmodning at jeg lovede at forære Enhver af Banden et Portrait. Byen er nu meget tyndt besat med Militair, det var derfor yderst frapperende at see at 13rle Regiment blev indskibet for at afgaa til Fyen, 3 Batteri var gaaet iforveien og Lazaretherne vare rømmede. Men endnu værre var det da der kom Ordre til at tage alle riflede Kanoner netl af Volde og Skandser og indskibe dem, efter Forlydende til Kystbatterier paa Fyen. Men denne Historie var saa tydelig at vi nu ikke længere tvivlede paa at Byen skulde rommes.... ${ }^{58}$ )

27. - Idag syntes det som om vi dog skulde blive, thi der blev givet Ordre til at sænke alle Kononerne i alle Værkerne 11/2 Fod og gjøre Traverserne ${ }^{59}$ ) 4 Alen tykkere, men om Middagen kom der Ordre til at hele Styrken skulde afgaae imorgen tidlig Kl 4 til Fyen; og kun efterlade 200 mand Artilleri samt 3 Compagnier Infanteri.

se) Det er for meget sagt. Reservens fremrykning kulminerede $i$ en kamp ved Dybbøl mølle.

57) Egum og Egeskov syd for Randsfjord på bægge sider af Vejlby.

s8) Fredericias rømning fandt sted u(len kamp 26.-28. april.

so) 5: Dækningerne. 
I)t var haardt, men der var jo ikke Noget at gjare derved, vi beklagede mest de Iriasser der skulde blive og rimeligvis ville falde $i$ Fjendens Kløer og derved gjøre en Reise til Spandau ${ }^{\text {an}}$ ) eller et andet rart Sted. Der blev givet Befaling til efter Kl 4 imorgen ticllig ikke at losne et Skud, Kanonerne matte ikke fornagles ${ }^{6 .}$ ) alt skulde blive staaende....

28. - Kl henved 5 Morgen afgik vi fra Fredericia og kom til Baaringvig Kl 6. Vi skulde nu i Quarteer. Vi marcherede derfor til Cathrineberg en Miils Vei derfra henimod Fredericia. Vi ankom til Cathrineberg Molle Kl $71 / 2$ og leirede os nu omkring Møllen i Græsset ventende paa Qvarteerbilletter.... Endelig da Kl var 4 bleve vi underrettede om at her ingen Plads var, hvorfor vi maatte marchere af igjen. Atter kom vi til Baaringvig, denne Gang ligesaalirt for at hlive der som den forrige, vi maatte tvertimod marchere videre ad Bogense til for muligvis at blive indqvarterede $i$ nogle Landsbyer i Nærheden. Kl 10 kom vi til Skovby Kirke, 1/2 Mils Vei fra Bogense, her gjorde vi Holdt, Kl 1 fik vi endelig vore Qvarteersedler, jeg maatte med mine Folk tractske til Skodstrup ${ }^{62}$ ) en stiv halv Mil borte, og formedelst Morke og Ibekjendtskab med Veiene gik vi naturligvis en Omvei saa at den blev over $1 \mathrm{Mil}$; endelig Kl $21 / 2$ kom vi i Qvarteer, hvor jeg med Folkene blev foret med Aggekage.

29. [Beskrivelse af kvarteret] ... IRundt onkring har man IIumlehaver, der $i$ clenne Tid see noget løierlige ud, da man kun seer Masser af lange, jeg kunde sige hoist meget lange Kjeppe der ruge op i Luften, naar Humlen derimod belækkker disse Stænger maa de see meget smukke ud. Man synes at have mange $Æ g$ her, thi inat da jeg kom fik jeg Eggekage med Flæsk, til Frokost Flæsk med Røræg, til Middag Eggekage. Skal det blive ved hver Dag bliver det lidt kjedeligt i Læengden. Kl 5 stillede jeg med hele Mandskabet ved Capitainens Qvarteer $1 / 2$ Mils Vei herfra. Her fik jeg mine 1:2 Mand igjen som jeg havde maattet lade hlive tilbage i Fredericia de havile faaet vore Kanoner fornaglede, og Materiellet adelagt samt gravet Projektilerne ned....

30. - Mandskabet havile anmodet mig on Tilladelse til at holde Dancisebal iaften, hvilket jo omtrent var synonymt med at bede mig holde Bal for dem, og jeg havde tilstaaet dem deres Bøn. Jeg blev irlag atter tracteret med $£ g$ til Frokost og Midclag. Om Eftermiddagen var jeg ovre i Møllen ${ }^{* 3}$ ) og da jeg kom tilbage var Dandsebal-

60) Hंvor der var fangelejr.

6) De blev dog fornaglede, jvf. 29. apr.

o2) Skåstrup ved Båringvig.

*3) Skovmollen, hvor Schnack og Larsen logerede. 
let i fuld Gang. Der var imidlertid ikke mere end en halv Snees vamer til 60 Mandfolk. Mandskabet klagede over at der havde været flere udenfor, men 4de Skandses Mandskab, der ikke lever saa patriarkalsk med deres Officerer som mit, vare misundelige over at 5te Skandse holdt Dandsebal, hvorfor de havde opholdt dem udenfor og paa en eller anden Maade fik Pigerne lokkede fra at gaae ind, jeg sendte nu Patrouiller ud for at forhindre Sligt, men nu var det for seent og vi fik ikke flere Damer den Gang. Forresten savnerles de egentlig ikke, thi de 10 der vare der holdt udmærket godt ud og dandsede med hele Banden hele Natten .... [N. blir hyldet af soldater, bønder og musikanter]. Hvad der glædede mig overordentligt, og forresten var temmelig mærkeligt, da der var 60 Mennesker samlede var, at der ikke var Spor af Kjævleri eller Drukkenskah, naturligvis bleve Folk lidt lystige tilsidst, men der var slet ikke Tale om at overskride Velanstændighedens Grændser. Nogle tnkelte Mand af \&de Skandse der trængte ind og ikke vilde ud maatte jeg med egen høie Haand smide paa Porten, forresten gik Natten aldeles uden Forstyrrelser. Pigerne dandsede, med en enkelt Undtagelse, meget gorlt, og saae efter Oinstandighederne meget ordentlige ud, og vi svingede os derfor lige til det blev Dag. Naar en aỉ Mandskabet opdagede en Pige der clandsede godt, skulde hun ju strax hen til Lieutenanten. De sidste to Timer dandsede jeg med Træsko paa da mine Fødder vare blevne noget omme, men det gik urimærket og da jeg endelig Kl $4 \frac{1 / 2}{2}$ havde faaet dem (Folkene) paa Porten gik jeg i Seng.

\section{Mai.}

1. - Intetsomhelst at bemærke.

[2-3. urlen interesse. 4. maj mangler optegnelser i dughogen.]

5. - Idag fik jeg Ordre til at overgaae til 1ste Compagni, til stor Bedrøvelse for mig, da jeg ved 2let Comp. havde det ganske udmærket og umuligt kunde finde en bedre Compagnicommandeur og paa samme Tid god Kammerat som Capt. Schnidt.

[6. 11. omtales afskedsgilder, afmarch til Middelfart og kritik af boligforholdene i det batteri, N. skal betjene. Ørkesløshed.]

12. - Idag demonterede vi 2 af vore gamle 18 th Kanoner fra 1801. Batteriet, ler nemlig er af den Slags, at enhver Kugle der rammer gaaer lukt igjennem Brystværnet, skal bygges heelt om, men da der i Vaabenhvilebetingelserne staaer at Batterier etc. skulle forblive i samme Stand kommer der vel Contraordre. 
13. - Da det under en Vaabenhvile naturligvis er unødvendigt at jeg ligger ude i Hulen ved mit Batteri flyttede jeg idag ind til Byen hvor jeg kom til at boe hos en Skomager Greve. Om Aftenen spillede jeg en Lhombre med Rasmussen, Svendsen og David.

14. - Jeg staar nu op om Morgenen Kl 61/2 i Regelen, spadserer ud til Kongebrogaarden hvor jeg spiser Frokost, derefter gaaer jeg ud og hilser paa mine Folk og driver saa omkring i Skoven eller ved Stranden til jeg skal spise til Middag, hvilket ogsaa skeer paa Kongebrogaarden. Efter Middag gaaer jeg saa ind til Byen og søger at faa Tiden til at gaa paa bedste Maade hvilket forresten i Reglen kan være vanskeligt nok. Da jeg i Middags var faa Kongebrogaarden fik jeg Underretning om at min gamle Capitain, Schmidt tilligemed Schnack vare komne til Byen for at besøge mig. Saasnart jeg havde spist benede jeg derind, men da jeg kom ind paa Gjæstgivergaarden vare Capitainen og Schnack gaaede ud til Kongebroen for at lede efter mig. De kom imidlertid tilbage, Gjensynet var rørende. Jeg maatte naturligvis spise til Middag med dem paa Gjæstgivergaarden hos Jacobsen....

[15. - slutter dagbogen med at skildre en udflugt til Hindsgavl og Fænø med påfølgende lystigt sold på Kongebrogården.] 